\title{
Pitfalls of the Past: Learning Disabilities that Hinder TRADOC’s Institutional Agility
}

\author{
A Monograph \\ by \\ MAJ Brett N. Bardo \\ United States Army

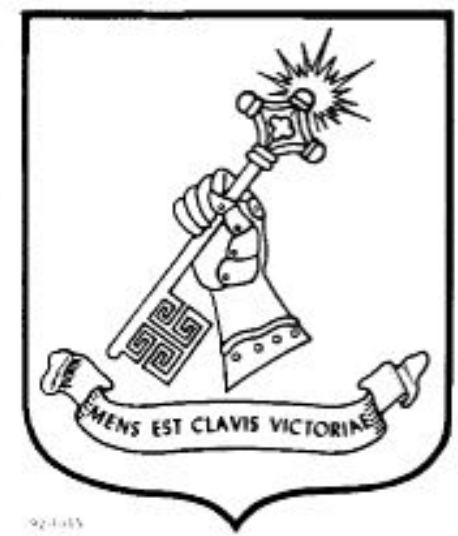 \\ School of Advanced Military Studies \\ United States Army Command and General Staff College \\ Fort Leavenworth, Kansas \\ 2015-01
}

Approved for public release; distribution is unlimited 


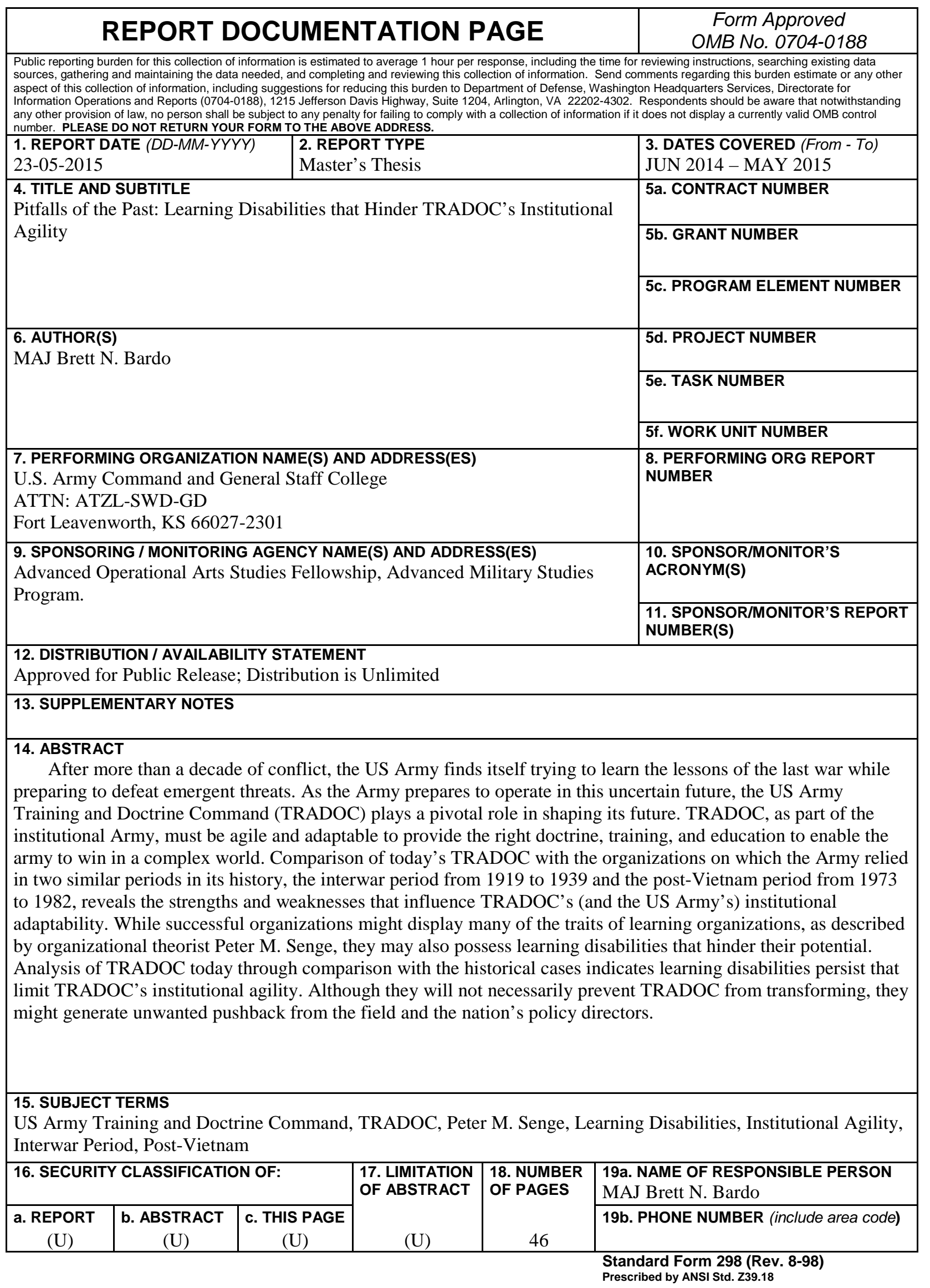




\section{Monograph Approval Page}

Name of Candidate: MAJ Brett N. Bardo

Monograph Title: $\quad$ Pitfalls of the Past: Learning Disabilities that Hinder TRADOC's Institutional Agility

Approved by:

Mark T. Calhoun, PhD

, Monograph Director

Michael R. Rayburn, COL

, Seminar Leader

Henry A. Arnold III, COL

, Director, School of Advanced Military Studies

Accepted this 23rd day of May 2015 by:

Robert F. Baumann, PhD

, Director, Graduate Degree Programs

The opinions and conclusions expressed herein are those of the student author and do not necessarily represent the views of the U.S. Army Command and General Staff College or any other government agency.(References to this study should include the foregoing statement.) 


\begin{abstract}
Pitfalls of the Past: Learning Disabilities that Hinder TRADOC's Institutional Agility, by MAJ Brett N. Bardo, United States Army, 45 pages.

After more than a decade of conflict, the US Army finds itself trying to learn the lessons of the last war while preparing to defeat emergent threats. As the Army prepares to operate in this uncertain future, the US Army Training and Doctrine Command (TRADOC) plays a pivotal role in shaping its future. TRADOC, as part of the institutional Army, must be agile and adaptable to provide the right doctrine, training, and education to enable the Army to win in a complex world. Comparison of today's TRADOC with the organizations on which the Army relied in two similar periods in its history, the interwar period from 1919 to 1939 and the post-Vietnam period from 1973 to 1982, reveals the strengths and weaknesses that influence TRADOC's (and the US Army's) institutional adaptability. While successful organizations might display many of the traits of learning organizations, as described by organizational theorist Peter M. Senge, they may also possess learning disabilities that hinder their potential. Analysis of TRADOC today through comparison with the historical cases indicates learning disabilities persist that limit TRADOC's institutional agility. Although they will not necessarily prevent TRADOC from transforming, they might generate unwanted pushback from the field and the nation's policy directors.
\end{abstract}




\section{Contents}

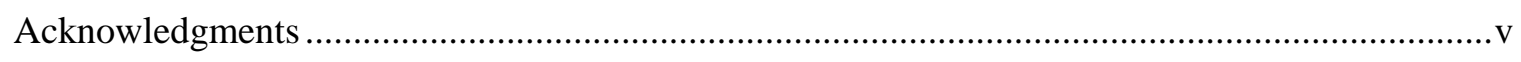

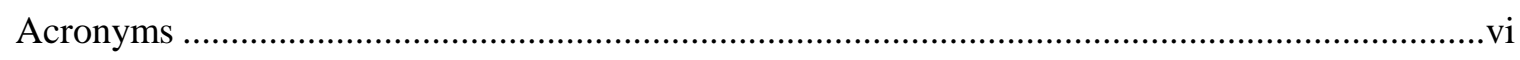

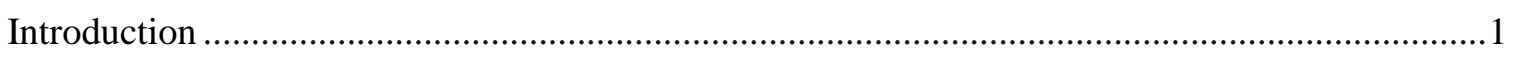

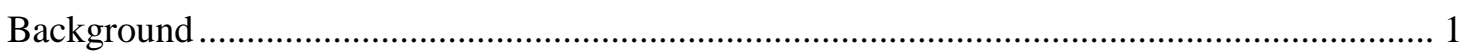

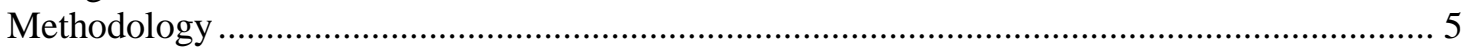

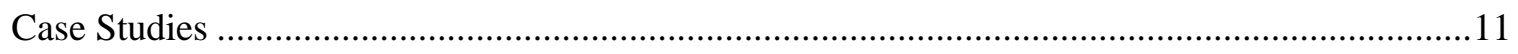

The Interwar Period ....................................................................................................... 11

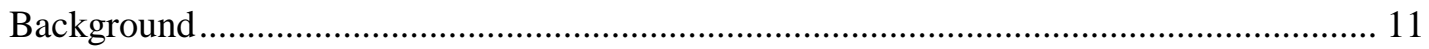

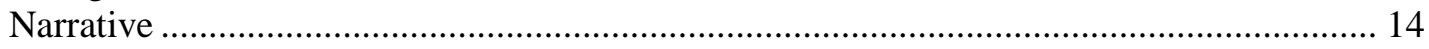

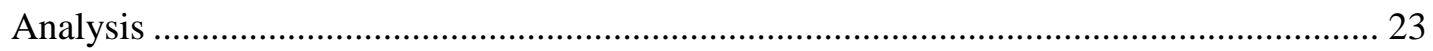

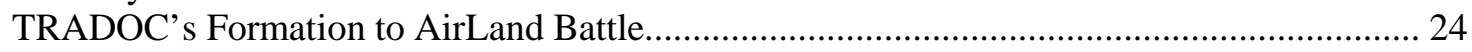

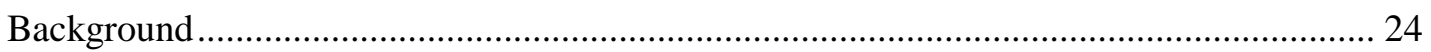

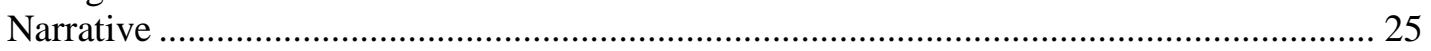

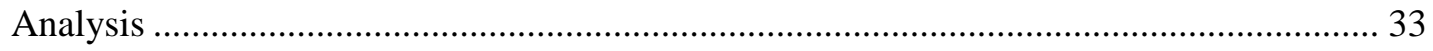

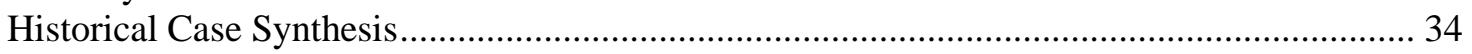

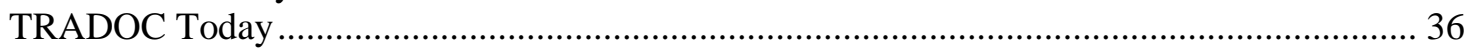

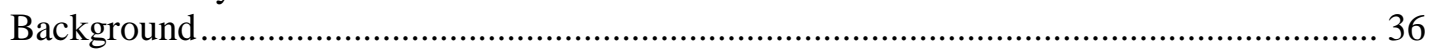

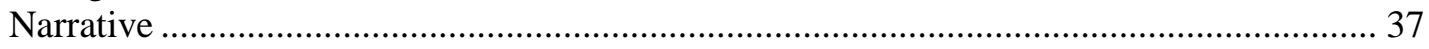

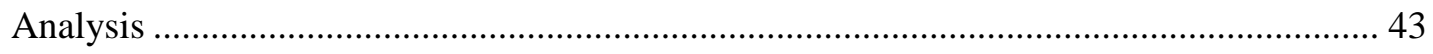

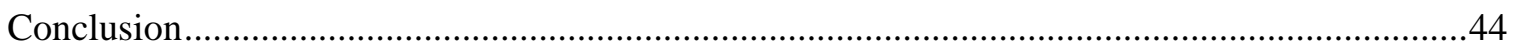

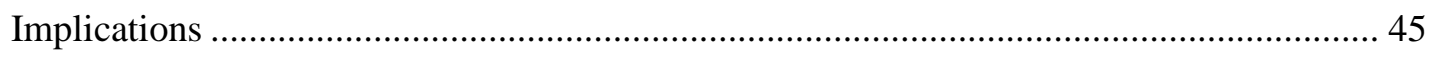

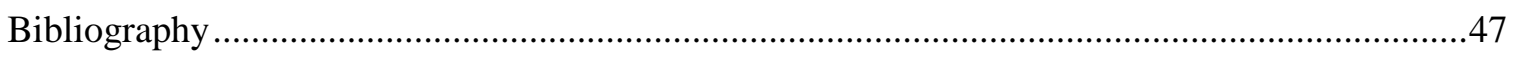




\section{Acknowledgments}

I would like to thank Dr. Mark T. Calhoun for his patience and unwavering support.

Additionally, I would also like to thank my fellow classmates for their guidance and encouragement, and COL Michael Rayburn for his mentorship. Finally, and most importantly, I would like to thank my wife Hilde for her support, encouragement, and understanding. 


\section{Acronyms}

\begin{tabular}{|c|c|}
\hline $\mathrm{ADP}$ & Army Doctrine Publication \\
\hline $\mathrm{AEF}$ & American Expeditionary Force \\
\hline ARTEP & Army Training and Education Program \\
\hline ARSW & Annual Report of the Secretary of War \\
\hline AWC & Army War College \\
\hline CAC & Combined Arms Center \\
\hline CGSC & US Army Command and General Staff College \\
\hline CGSS & US Army Command and General Staff School \\
\hline COIN & Counterinsurgency \\
\hline CONARC & US Army Continental Army Command \\
\hline CTC & Combat Training Center \\
\hline FM & Field Manual \\
\hline FSR & Field Service Regulations \\
\hline ILE & Intermediate Level Education \\
\hline MCLU & Manual for Commanders of Large Units \\
\hline MMAS & Masters of Military Arts and Science \\
\hline NTC & National Training Center \\
\hline OEF & Operation Enduring Freedom \\
\hline OIF & Operation Iraqi Freedom \\
\hline SMTC & Soldier's Manuals of Common Tasks \\
\hline TC & Training Circular \\
\hline TRADOC & US Army Training and Doctrine Command \\
\hline ULO & Unified Land Operations \\
\hline WDGS & War Department General Staff \\
\hline
\end{tabular}




\section{Introduction}

Following more than a decade of conflict consisting predominantly of stability and counterinsurgency operations, the US Army finds itself trying to learn the lessons of the last war, determine the future operational environment, and shape the Army to defeat the threats of that environment. As the Army transitions to operate in this uncertain future, the US Army Training and Doctrine Command (TRADOC) plays a pivotal role in shaping the future Army. In October 2014, the US Army published the U.S. Army Operating Concept to provide guidance and describe how the Army will support the nation in an increasing complex world. While well intentioned, this guidance might place TRADOC in the difficult position of lacking the required resources and operational experience — and in particular, sufficient agility — to provide adaptive doctrine, training, and education. ${ }^{1}$

\section{Background}

The Army Operating Concept expanded upon The U.S. Army Capstone Concept, published in 2012. According to the Army Capstone Concept, the fundamental characteristic that enables the Army to "provide decisive landpower is operational adaptability.” To be operationally adaptable, the Army requires agile and adaptive organizations and institutions that can respond appropriately to changes in the operational environment. To meet this, the Army looks to its institutional Army to lead the way in adaptability. TRADOC, as part of the institutional Army, must be agile and adaptable to provide the right doctrine, training, and education to enable the Army to win in a complex world. ${ }^{2}$

${ }^{1}$ Training and Doctrine Command (TRADOC) Pamphlet 525-3-0, The U.S. Army Capstone Concept (Fort Eustis, VA: Headquarters, Training and Doctrine Command, 2012), 4-5, 11; TRADOC Pamphlet 525-3-1, The U.S. Army Operating Concept: Win in a Complex World (Fort Eustis, VA: Headquarters, Training and Doctrine Command, 2014), 5.

2 TRADOC Pamphlet 525-3-0, 11, 18-19; US Army Training and Doctrine Command, 
Comparison of today's TRADOC with organizations in two similar periods in the US Army's history reveals the strengths and weaknesses that influence TRADOC's (and the US Army’s) institutional adaptability. Like today, the interwar period from 1919 to 1939 and the post-Vietnam period from 1973 to 1982 were transition periods for the Army that each serve as excellent cases to study in search of insight regarding the challenges TRADOC currently faces. In the years before each case study, the Army fought in wars that changed the way the Army thought about and engaged in warfare. During these periods, the Army adapted its doctrine, training, and education institutions that set the foundation for the Army’s success in subsequent wars.

The interwar period highlights the US Army's efforts to modernize and prepare for future war in a manner consistent with the American view of warfare. Although TRADOC did not exist until 1973, the Army War College (AWC) and the Command and General Staff School (CGSS) served as the intellectual centers of the Army during the interwar period in much the same way that they do today. Following the Army's short but significant experience on the World War I battlefields, the Army's leaders and officers, many of whom were students at the War College and CGSS, sought to determine the Army’s future while facing a shrinking budget and a downsized Army. They did this through the Army's most comprehensive process of post-war boards and self-assessments conducted to that point in the Army's history, which then informed the post-war curriculum and doctrine that the Army used through most of the next two decades. ${ }^{3}$

“About TRADOC,” US Army Training and Doctrine Command, October 28, 2014, accessed March 28, 2015, http://www.tradoc.army.mil/About.asp.

${ }^{3}$ Jean R. Moenk, Operation STEADFAST Historical Summary: A History of the Reorganization of the U.S. Continental Army Command (1972 - 1973) (Fort Monroe, VA: U.S. Army Training and Doctrine Command, 1974), 8; Peter J. Schifferle, America's School for War: Fort Leavenworth, Officer Education, and Victory in World War II (Lawrence: University of Kansas Press, 2010), 9-17, 188-96. The Command and General Staff School was renamed to the Command and General Staff College (CGSC) in 1947. Any references to CGSC before 1947 will refer to it as CGSS. 
Peter Schifferle in his America's School for War: Fort Leavenworth, Officer Education, and Victory in World War II examined how officer education at CGSS at Fort Leavenworth, Kansas contributed to the Army's success in World War II. Schifferle argued that the education at CGSS played a critical role by creating officers with the skills and confidence to solve problems and lead large formations. Schifferle's analysis described how the Army made use of the concentration of intellectual energy at CGSS to analyze the lessons of World War I and disseminate them throughout the force in preparation for future conflict, in Europe or one of many other contingencies. ${ }^{4}$

In Carrying the War to the Enemy: American Operational Art to 1945, Michael Matheny argued that American operational art developed not in its doctrine but the "student texts, exercises, and curriculum of the postgraduate military schools.” Matheny described how the education of officers at CGSS and the War College shaped Army doctrine, strategy, and war plans during the interwar period and how those efforts contributed to the Army's success in World War II. Judith Hicks Stiehm in U.S. Army War College: Military Education in a Democracy examined the history of the AWC curriculum. Stiehm agreed with Elihu Root's assessment that the War College and military educational institutions like it served in a democratic society, "not to promote war, but to preserve peace.”5

TRADOC, formed in 1973 to bring much-needed structure and standardization to postVietnam era training and education, faced the challenge of accomplishing its mission during one of the worst periods in the Army's history. The Army in the post-Vietnam War era experienced a great deal of turbulence as it struggled to reinvent itself while recovering from the difficult

${ }^{4}$ Schifferle, 9-17, 188-96.

${ }^{5}$ Michael R. Matheny, Carrying the War to the Enemy: American Operational Art to 1945 (Norman, OK: University of Oklahoma Press, 2011), 49; Stiehm, Judith H., In the Wake of War: U.S. Army War College: Military Education in a Democracy (Philadelphia: Temple University Press, 2002), 4, 195-200. 
experience of the Vietnam War. Assisting it in its mission, TRADOC in the 1970s benefited from the existence of a real and known threat, the Soviet Union. This specificity of threat eased the challenge of developing the next doctrine, education, and training methods. ${ }^{6}$

Further assistance in overcoming the institutional memory of Vietnam came in the form of the 1973 October (Arab-Israeli) War. The war provided the newly organized TRADOC a template both to realign its focus on traditional, conventional threats, and on which to base a new doctrine focused on the combined arms, mechanized conventional warfare many observers foresaw as the Army's next war, likely to take place in central Europe. This transition period culminated with the Army's adoption of the 1982 version of Field Manual (FM) 100-5 Operations, known as AirLand Battle. ${ }^{7}$

TRADOC’s first commander, General William E. DePuy, led the Army through this period of doctrinal and organizational transformation. DePuy directly influenced TRADOC’s transformation and the publication of the Army's first doctrine that addressed the threat that the Soviet Union represented to Europe. DePuy’s writings and interviews provide insight on his perspective on the role of training and education in the Army, and how he shaped TRADOC's early years. John L. Romjue, Susan Canedy, and Anne W. Chapman's Prepare the Army for War: A Historical Overview of the Army Training and Doctrine Command, 1973-1993 provided a

${ }^{6}$ Marilyn B. Young, The Vietnam Wars 1945-1990 (New York: HarperPerennial, 1991), 281-89; Harry G. Summers, Jr., On Strategy: A Critical Analysis of the Vietnam War (New York: Presidio Press, 1995), 1-7. Summers' analysis of the Army during the Vietnam War examines why the Army was disillusioned about its “tactical victories.” His 1981 US Army War College paper and subsequent 1982 publication is an example of Army officers seeking to understand the defeat in Vietnam, and sought to break the "Vietnam Syndrome" and achieve success on the battlefield.

${ }^{7}$ Paul H. Herbert, Deciding What Has to Be Done: General William E. DePuy and the 1976 Edition of "FM 100-5, Operations," Leavenworth Papers No. 16 (Fort Leavenworth, KS: Combat Studies Institute, 1988), 25-36; Field Manual (FM) 100-5, Operations (Washington, DC: Government Printing Office, 1982), 1-5. FM 100-5 introduced the term AirLand Battle and used the atypical capitalization. 
comprehensive overview of the organizational changes and doctrine development from

TRADOC's inception through the Army's success in the 1991 Gulf War. $^{8}$

In each of these cases, agility and the ability to adapt to emerging characteristics of warfare enabled the Army to update its doctrine, education, and training, even in periods of fiscal constraint and austerity. While the Army Capstone Concept identified adaptability as a critical Army characteristic, TRADOC’s procedures place constraints on the degree of agility that TRADOC can attain, making it doubtful that today's TRADOC can accomplish the kind of change experienced in the interwar period and the post-Vietnam period. Hindered by these constraints, TRADOC does not possess sufficient agility as required by The Army Capstone Concept. The following analysis demonstrates these shortcomings present in TRADOC and identifies the risk this presents to today's Army as it seeks to prepare for the challenges of the future.

\section{Methodology}

TRADOC's procedures and organizational structures hinder its ability to create dynamic and adaptive doctrine, training, and education. Unless TRADOC adjusts its current structure and procedures, it will not meet the Army Capstone Concept's intent of an adaptive institutional Army. The U.S. Army Capstone Concept serves as a foundation for the analysis that follows. Previously published concepts and doctrine inform one's understanding of TRADOC's role in

${ }^{8}$ Richard M. Swain, Selected Papers of General William E. DePuy: First Commander, U.S. Army Training and Doctrine Command, 1 July 1973, ed. Donald L Gilmore and Carolyn D. Conway (Fort Leavenworth, KS: Combat Studies Institute, 1994); Romie L. Brownlee and William J. Mullen, III, Changing an Army: An Oral History of General William E. DePuy, USA Retired (Carlisle Barracks, PA: United States Military History Institute, 1987); John L. Romjue, Susan Canedy, and Anne W. Chapman, Prepare the Army for War: A Historical Overview of the Army Training and Doctrine Command, 1973-1993 (Fort Monroe, VA: Headquarters, Training and Doctrine Command, 1993). 
providing training and education. Evaluation of US Army concepts and doctrine, as well as previous works on military education, supports this preliminary survey, which leads to an assessment of the current state of US Army education.

Identification of characteristics common to agile and adaptive institutions in the historical cases - including in particular those that led to the development of relevant doctrine, training, and education that prepared for emerging threats—reveal continuities that TRADOC should seek to either retain or avoid. This enables analysis of The Army Capstone Concept's idea of institutional agility, and assessment of its contribution to US Army operational art. This analysis provides evidence to test the hypothesis, demonstrating its validity, and leading to identification of recommendations and implications to inform TRADOC and enhance its contribution to an adaptive and agile US Army.

Agile and adaptive institutions are inherently learning organizations. Learning organization theory developed in the 1960s and 1970s based on observations on business management. Learning organization theory's business world foundations kept its application in business until John Nagl's Learning to Eat Soup with a Knife: Counterinsurgency Lessons from Malaya and Vietnam popularized organizational learning theory application in the military. Nagl based his study’s theoretical framework on Richard Downie’s institutional learning cycle. ${ }^{9}$

Downie’s institutional learning cycle integrated previous organizational learning cycles and applied them to the military’s decision-making process while developing doctrine. Downie’s learning cycle has similarities to both Colonel John Boyd's decision-making cycle and Peter M.

${ }^{9}$ For early learning organization theories see Chris Argyris and Donald A. Schön, Organizational Learning: A Theory of Action Perspective (Reading, MA: Addison-Wesley Publishing Company, 1978); James March and Johan P. Olsen, Ambiguity and Choice in Organization (Oslo: Universitetsforlaget, 1976); and Gerald Zaltman, Robert Duncan, and Jenny Holbeck, Innovation in Organizations (New York: John Wiley \& Sons, 1973); John A. Nagl, Learning to Eat Soup with a Knife: Counterinsurgency Lessons from Malaya and Vietnam (Chicago: The University of Chicago Press, 2005), xxiii, 4-8. 
Senge's individual and team learning wheels. All three theories developed around the idea that individuals and organizations learn cyclically though observation, generating options, deciding, and assessing actions. ${ }^{10}$

In The Fifth Discipline: The Art \& Practice of the Learning Organization Peter M. Senge described learning organizations and defined the disciplines that learning organizations master. Senge described organizations as complex systems, best suited for analysis through systems thinking, his fifth discipline, which in his view demonstrates that through management based on a systems approach, organizations can become learning organizations. Some readers criticized Senge for reducing his approach to four disciplines with systems thinking as an all-encompassing discipline and by excluding other systemic theories. ${ }^{11}$

While Senge has his critics, his books remain popular, and many readers consider his work a valid framework for evaluating organizations. Authors across many disciplines still use Senge’s theory to include business, education, and the military. Senge’s 2006 revision of The Fifth Discipline provided testimony from business leaders who implemented Senge's theory.

${ }^{10}$ Richard D. Downie, Learning from Conflict: The U.S. Military in Vietnam, El Salvador, and the Drug War (Westport, CT: Praeger, 1998), 34-38; Robert Coram, Boyd: The Fighter Pilot Who Changed the Art of War (Boston: Brown Little, 2002), 327-44; Peter M. Senge et al., The Fifth Discipline Fieldbook: Strategies and Tools for Building a Learning Organization (New York: Doubleday, 1994), 69-54.

${ }^{11}$ Peter M. Senge, The Fifth Discipline: The Art \& Practices of the Learning Organization (New York: Random House, Inc., 2006), 6-7, 11-12, 68-69; Dennis J. Moberg, “Diagnosing System States: Beyond Senge’s Archetypes," Emergence 3, no. 2 (Lawrence Erlbaum Associates, Inc., 2001), 19-36. Moberg argued that Senge's disciplines are too generic and do not encompass all factors needed to analyze a system. Moberg recommended including "symptoms, critical thinking, pattern recognition, and boundary conditions" for effective systems analysis; Robert L. Flood, Rethinking the Fifth Discipline: Learning Within the Unknowable (London: Routledge, 1999), 67-73. Flood argued that Senge constrains his analysis by approaching systems thinking only through systems dynamics and does not provide "a wideranging and coherent theory of systemic thinking.” Flood compares Senge's theory of action against five complexity theorists and offers how their theories if incorporated by Senge would produce a greater encompassing work; See also Mark T. Calhoun, "Complexity and Innovation: Army Transformation and the Reality of War” (monograph, US Army Command and General Staff College, 2004) 41-45. 
Additionally, Senge adapted his theory for educators with his Schools That Learn, which provided feedback and successes from educators. As the Army's primary learning organization, TRADOC is an institution that would benefit from applying Senge’s theories. ${ }^{12}$

One can see the significance of individual and organizational learning to the Army, given the frequency with which the Army’s Capstone Concept, Operating Concept, and its doctrinal publications on Army leadership mention these forms of learning. Although debate continues regarding the question of whether one should even consider the Army a learning organization, this study views as a given TRADOC's nature as a learning institution, allowing the analysis to focus on those factors that limit TRADOC from operating at its full potential. ${ }^{13}$

While successful organizations might display many of the traits of learning organizations, they may also possess what Senge called learning disabilities that hinder their potential. Senge wrote, "It is no accident that most organizations learn poorly. The way they are designed and managed, the way people’s jobs are defined, and, most importantly, the way we have all been

${ }^{12}$ Barbara Kohm and Beverly Nance, Principals Who Learn: Asking the Right Questions, Seeking the Best Solutions (Alexandria, VA: Association for Supervision and Curriculum Development, 2007); Peter M. Senge et al., Schools That Learn: A Fifth Discipline Fieldbook for Educators, Parents, and Everyone Who Cares About Education (New York: Doubleday, 2000); Senge, 258-376.

13 TRADOC Pamphlet 525-3-0; TRADOC Pamphlet 525-3-1; Army Doctrine Publication (ADP) 6-22, Army Leadership (Washington, DC: Government Printing Office, 2012); Army Doctrine Reference Publication 6-22, Army Leadership (Washington, DC: Government Printing Office, 2012); For analysis on the Army as a learning organization see Stephen J. Gerras, "The Army as a Learning Organization” (research paper, US Army War College, 2002); Kareem P. Montague, “The Army and Team Learning” (monograph, US Army Command and General Staff College, 2008); John D. Williams, “Is the U.S. Army a Learning Organization?” (Strategy research project, US Army War College, 2007); Anthony J. DiBella, "Can the Army Become a Learning Organization? A Question Reexamined,” US Army News, accessed 01 Nov 2014, http://www.army.mil/article/36320/Can_the_Army_Become_a_Learning_Organization _039_A_question_reexamined/. 
taught to think and interact...create fundamental learning disabilities.” Senge’s organizational learning disabilities build the foundation for case study evaluation criteria: ${ }^{14}$

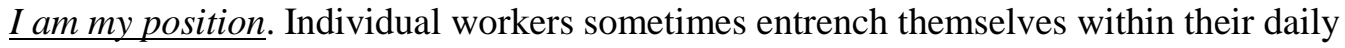
duties, losing visibility on the organization as a whole. They can "describe the tasks they perform every day, not the purpose of the greater enterprise in which they take part.” This is similar to Downie’s second hypothesis, organizational resistance, as military organizations resist change due to institutional norms. ${ }^{15}$

The enemy is out there. This disability expands upon the previous disability in that workers who concentrate on their jobs can fail to see the impacts of their actions beyond their position. When errors occur, our "propensity [is] to find someone or something outside ourselves to blame." Often, the fault is not external but internal; however, the perception is to the contrary. This is similar to Downie's seventh hypothesis, organizational defensive barriers, in that military organizations prevent change by creating defensive barriers. ${ }^{16}$

The illusion of taking charge. The Illusion of Taking Charge stems from organizations reacting to problems while thinking they are being proactive. Often, "proactiveness is reactiveness in disguise.” Reactive organizations attack the "enemy out there” rather than examining internal contributions to problems within the environment. Downie's fifth hypothesis, organizational failure, states that organizations change in response to incidents of failure. ${ }^{17}$

The fixation on events. This disability occurs when organizations react to the most recent and observable events instead of the underlying gradual processes. Organizations should not be reacting to events but examining the long-term processes that led to those events. Lessons learned

${ }^{14}$ Senge, 17-26.

${ }^{15}$ Downie, 30-34; Senge, 18-19, 51-52.

${ }^{16}$ Downie, 34-37; Senge, 19-20, 51-52.

${ }^{17}$ Downie, 30-34; Senge, 20-21, 51-52. 
and new tactics, techniques, and procedures can solve immediate threats but are not long-term solutions for organizations. Like Downie's fifth hypothesis, organizations may focus too much on immediate failures. ${ }^{18}$

The parable of the boiled frog. The parable is a frog placed in boiling water will jump out but a frog placed in room temperature water that slowly heats up will boil to death. Organizations operate at a rapid pace; however, to see slow moving threats, organizations must learn to slow down. This is also similar to Downie's second hypothesis as norms and culture may not permit time to slow down. ${ }^{19}$

The delusion of learning from experience. This disability derives from organizations learning from their experiences but not understanding the consequences from decisions made from those experiences. As organizations expand, they divide labor into subordinate divisions, which creates stovepipes of information and decision-making. The delusion occurs as time progresses and organizations lose the ability to assess decisions' effects. ${ }^{20}$

Myth of the management team. The Myth of the Management Team stems from "most managers finding collective inquiry inherently threatening.” Assessment is an important function within the Army as it seeks to improve upon every completed action. Organizations tend to avoid bad assessments and establish barriers to protect themselves. These barriers hinder organizational learning. This disability also is similar to Downie’s seventh hypothesis. ${ }^{21}$

Comparative historical case analysis enables evaluation of current US Army doctrine, training, and education. This includes historical case studies of both the AWC and Command and General Staff College (CGSC) during the interwar period, and TRADOC’s schools and

${ }^{18}$ Senge, 21-22, 51-52.

${ }^{19}$ Downie, 30-34; 22-23, 51-52.

${ }^{20}$ Senge, 23-24, 51-52.

${ }^{21}$ Downie, 34-37; Senge, 21-25. 
headquarters during the post-Vietnam era (1973 through 1982). These two case studies provide the foundation for the final case study of TRADOC from 2008-2014, focusing on its doctrine development, training, and education. The Army today, much like in the other historical periods, faces a shrinking budget and downsizing force. Somehow, TRADOC, as the organization responsible for training and educating Army leaders, must overcome these constraints and prepare the Army for the challenges of a complex world.

\section{Case Studies}

The Interwar Period

\section{Background}

World War I was unique in how technological innovations shaped the battlefield and forced the opposing armies to adapt their formations, doctrine, and tactics. At the onset of World War I, the armies engaged in linear tactics with infantry and cavalry maneuvering on the battlefield, largely unsupported by the other arms. However, on the Western Front, where huge armies crowded compact battlefields, “Modern weapons allowed armies to set up impregnable defensive positions, and neither the officer corps nor the general staffs worked out how to use modern technology, or evolved tactical concepts to break through such defenses....”22

From 1914 to 1918, armies changed their conduct on the battlefield to defeat the operations and tactics of the previous year. In 1914, commanders relied upon open maneuver instead of firepower and defensive positions to defeat their enemies. Germany’s Schlieffen plan exemplified this height of maneuver warfare in World War I. German logistical problems, tactical

\footnotetext{
${ }^{22}$ Williamson A. Murray, “The West at War,” in The Cambridge History of Warfare, ed. Geoffrey Parker (New York: Cambridge University Press, 2005), 278-83.
} 
errors, and determined British and French resistance created a stalemate along the battle lines in November 1914 as the armies dug trench lines to protect their forces. ${ }^{23}$

Over the course of the next four years, the nature of the warfare that took place continued to evolve. Technological advancements in artillery and machineguns increased their firepower and lethality, which strengthened the defense. This led to a reliance on firepower and hardened positions to seize and hold terrain. The introduction of tanks, chemical weapons, and aircraft on the battlefield increased the complexity, width, and depth on the battlefield. To cope, formations grew in size beyond the personal control of their commanders as the battlefield extended in all three dimensions. ${ }^{24}$

In 1918, the combatants finally began to find ways to conduct maneuver warfare with some degree of success on the long-stabilized front lines. By integrating firepower and maneuver in creative ways, attacking units suppressed and bypassed defensive positions on flanks while massing to defeat only those necessary to continue the advance. The British use of tanks at Cambrai in November 1917 and Amiens in August 1918, along with German General Ludendorff's sturmtruppen tactics of attacking in depth serve as examples of these new methods of maneuvering on a battlefield that still favored the defense. While the changes enabled limited

${ }^{23}$ Murray, 278-83; Jonathan B. A. Bailey, "The First World War and the Birth of Modern Warfare,” in The Dynamics of Military Revolution: 1300-2050, ed. MacGregor Knox and Williamson Murray (New York: Cambridge University Press, 2001), 132-53.

${ }^{24}$ Murray, 278-79; Bailey, 132-53; James J. Schneider, “The Theory of the Empty Battlefield,” The RUSI Journal 132, no. 3 (September 1987): 37-44. Schneider described the empty battlefield as the paradox that while weapon lethality increased, casualty rates decreased. Schneider posited this is due to rifle technology simultaneously increasing lethality and survivability, increased dispersion on the battlefield, and unit moral cohesion. The increased dispersion reduced command and control's effectiveness, which reduced the intensity of firefights. 
local tactical success, the armies lacked the ability to achieve and maintain breakthrough operations; the Western Front remained locked in a stalemate. ${ }^{25}$

By late 1918, the American Expeditionary Force (AEF) sought a means to apply a uniquely American approach to fighting on the long-stabilized European battlefields by using firepower to enable maneuver. The AEF’s September 5, 1918 “Combat Instructions” exemplified this as it sought to integrate open and trench warfare into a coherent doctrine. With so much innovation in technology and tactics, the short-lived AEF and its leaders had to capture the lessons learned and determine the American way of war following World War I's conclusion. ${ }^{26}$

Before World War I, the US Army conducted primarily constabulary missions in the American west and its overseas protectorates. Few officers had attended CGSS and officer requirements for the 1916 Punitive Expedition withdrew both instructors and students from the schoolhouses. With the US Army's impending participation in World War I, the War Department shut down CGSS and other schools in 1916 to support the war effort. The limited number of graduates hindered the mobilization effort and operations in France as few officers had formal general staff officer training. ${ }^{27}$

In 1917, shortly after declaring war on Germany, the War Department selected General John J. Pershing as General-in-Chief of the AEF. General Pershing recognized the lack of general

${ }^{25}$ Murray, 301-9; Bailey, 143-46.

${ }^{26}$ American Expeditionary Force, “Combat Instructions,” General Headquarters American Expeditionary Force, September 5, 1918; Schifferle, 6-8.

${ }^{27}$ Mark E. Grotelueschen, The AEF Way of War: The American Army and Combat in World War I (New York: Cambridge University Press, 2007), 12, 24-25; Charles E. Heller, "World War I and the Interwar Years, 1916-1939," in A Brief History of Fort Leavenworth 18271983 ed. John W. Partin (Fort Leavenworth, KS: Combat Studies Institute, 1983) 34-37; David E. Johnson, "From Frontier Constabulary to Modern Army," in The Challenge of Change: Military Institutions and New Realities, 1918-1941, ed. Harold R. Winton and David R. Mets (Lincoln, NE: University of Nebraska Press, 2000), 163-66; John W. Partin, "Wars and New Challenges, 1939-1983,” in A Brief History of Fort Leavenworth 1827-1983 ed. John W. Partin (Fort Leavenworth, KS: Combat Studies Institute, 1983), 37-40. 
staff officer education and experience within the AEF. Brigadier General Hugh Drum recommended the establishment of an abbreviated general staff school in France, modeled after CGSS but modified to incorporate the French and British staff systems. Since French and British personnel delivered much of the instruction, the school had the added benefit of providing lessons learned from instructors who had months or even years of experience in the war. Over thirteen months the school at Langres, France completed four courses, graduating 500 students. While the school at Langres provided a temporary solution for the AEF, the Army would need a permanent solution to educate general staff officers and prepare the Army for the next war in Europe. ${ }^{28}$

Narrative

Following the Armistice in November 1918, the AEF and its leaders needed to capture the lessons learned before the wartime experience faded. While in France, Pershing directed multiple review boards to capture lessons learned from all branches and services within the AEF. Foremost among these was the AEF Superior Board on Organization and Tactics. Convened in April 1919, the board's mission was to review the findings of previous boards and provide recommendations. Concluding in July, the board emphasized the importance of a general staff with an operational planning staff down to the battalion level and stressed the importance of logistics to sustain armies. In a reversal from the AEF's battlefield experience, the board subordinated all arms, to include artillery, to supporting roles under the infantry. While the board emphasized the importance of infantry conducting offensive operations in open warfare, it still recommended massive firepower to defeat enemy infantry and neutralize their artillery. ${ }^{29}$

${ }^{28}$ James J. Cooke, Pershing and His Generals: Command and Staff in the AEF (Westport, CT: Praeger, 1997), 2, 21-26, 33-37; Grotelueschen, 25-26; Schifferle, 10-12.

${ }^{29}$ Grotelueschen, 352-55; Matheny, 46-47. William O. Odom, After the Trenches: The Transformation of U.S. Army Doctrine, 1918-1939 (College Station, TX: Texas A\&M University Press, 1999), 18-19, 26-28. 
Pershing criticized the Superior Board’s findings in his "Wrapper Indorsement” as the AEF commander. Pershing argued the AEF’s recent experiences in World War I too strongly influenced the board. According to Pershing, the board overemphasized the "stabilized warfare in Western Europe.” He also criticized the board’s stressed reliance on detailed attack plans based on artillery timetables. Pershing proposed a smaller division with fewer but more mobile supporting artillery pieces to maximize the ability to maneuver, breach, and exploit enemy lines. This vision significantly differed from the Superior Board recommendation to retain the massive divisions employed by the AEF on the Western Front. ${ }^{30}$

In 1920, Congress passed the National Defense Act, which changed the Army’s organization and structure. The 1920 National Defense Act, along with World War I's innovations in technology and tactics, required an update to Army doctrine. Then Army Chief of Staff, General Peyton C. March, directed a special committee to consider the Superior Board’s recommendations to determine how to implement the 1920 Defense Act's provisions.

Additionally, March directed the Training and Instruction Branch within the War Department General Staff's (WDGS) War Plans Division to review and revise tactical doctrine. Overwhelmed by the task, the Training and Instruction Branch solicited the assistance of the various branch schools. The AEF's and WDGS's efforts to capture the lessons learned from World War I were proactive and indicate the Army suffered neither from the illusion of taking charge nor became fixated on events. ${ }^{31}$

${ }^{30}$ John J. Pershing, "Wrapper Indorsement (Forwarding Report of A.E.F. Superior Board on Organization and Tactics)" (General Headquarters, A.E.F., 16 June 1920), 1; Grotelueschen, 354-55; Odom, 18-20.

${ }^{31}$ Matheny, 47-49; Odom, 28-30; National Defense Act of 1920, Public Law 242, $66^{\text {th }}$ Cong., 2d sess. (June 4, 1920). The act organized the Army into Regular, National Guard, and Reserve components, limited the Regular Army to 15,000 officers and 280,000 enlisted men, created the Chemical Warfare Service, Finance Department, and Air Service in the Regular Army, and established branch chiefs for each branch. 
In 1920, the WDGS War Plans Division tasked CGSS to update the 1914 Field Service Regulations (FSR). The 1914 FSR, last updated in 1918, differed little from the 1913 version. Both FSRs focused mostly on the tactical level employment of infantry, cavalry, artillery, and supporting sustainment branches. While the 1914 FSR included some tactical considerations from the World War I battlefield to include trenches and machine guns, it was completed before the AEF completed operations in France and conducted its numerous review boards. ${ }^{32}$

Pershing, as the Chief of Staff of the Army from 1921-1923, encouraged the WDGS to continue working with the schools and branches to revise the new doctrine. As chief of staff, Pershing reorganized the WDGS similar to the AEF's general staff structure and brought in proven AEF veterans he trusted. The newly organized War Department G3 Training Branch distributed copies of the draft FSR to all divisions within the WDGS, army schools, and the branch chiefs for comments. The WDGS divisions, branch chiefs, and the AWC heavily criticized the work for its discontinuity as it represented the collaboration of various authors at CGSS. The WDGS G3, incorporating the various criticisms, finalized the 1923 FSR in 1924. This collaborative approach to writing the 1923 FSR depicted an organization that did not stovepipe efforts and welcomed criticisms instead of protecting itself against them. Thus, the Army avoided the disabilities of the delusion of learning from experience and the myth of the management team..$^{33}$

The AEF Superior Board's recommendations initially influenced the writing of the 1923 FSR. While the new FSR drew from the AEF Superior Board, Pershing, as the Chief of Staff,

${ }^{32}$ Walter E. Kretchik, U.S. Army Doctrine: From the American Revolution to the War on Terror (Lawrence, KS: University of Kansas Press, 2011), 132-34; Matheny, 47-49; Odom, 3031; Field Service Regulations, United States Army 1913, corrected to May 21, 1913 (Washington, DC: Government Printing Office, 1913); Field Service Regulations, United States Army 1914, corrected to July 31, 1918 (Washington, DC: Government Printing Office, 1918).

${ }^{33}$ Cooke, 148-50; Kretchik, 132-34; Matheny, 48-89; Odom, 33-36. 
influenced the final version and did not allow any board recommendations he disagreed with into the FSR. It was revolutionary compared to its predecessors in that the FSR stressed the importance of combined arms on the battlefield, provided initial distinction between strategic policies and tactical missions, stressed decisive offensive operations using fire and maneuver, and defined nine fundamental principles of war. Additionally, the 1923 FSR addressed the employment of new battlefield technologies, tanks, aircraft, and poison gas. These changes reflect Pershing's view that American warfare should focus on open warfare opposed to the stabilized fronts on the Western Front. Pershing's criticisms of the Superior Board’s findings and suppression of its recommendations in the 1923 FSR displayed Senge's disabilities the myth of the management team and the enemy is out there. Additionally, Pershing's assignment of trusted AEF veterans to the WDGS stemmed from the delusion of learning from experience as Pershing and the WDGS shaped the FSR under Pershing's guidance. ${ }^{34}$

While the 1923 FSR emphasized the importance of the other arms, it still described them as subordinate to the infantry on the battlefield. Per the FSR, artillery, airplanes, and tanks “contributed to the execution of the infantry mission.” The infantry's power resided in superior morale and its ability to destroy the enemy's army in offensive operations. Through decisive victory on the battlefield, the infantry, supported by the other arms and branches, would defeat the enemy's will, forcing the opposing political leaders to sue for peace. While The 1923 FSR sought to prepare the Army for future wars, it still kept one foot in the past as it stressed combined arms but emphasized the infantry over all other arms. This fixation on events derived from the Army still clinging to the past and not fully accepting or understanding how World War

${ }^{34}$ Field Service Regulations, United States Army 1923 (Washington, DC: Government Printing Office, 1923), iv, 1-2, 11, 77-78, 88-100; Kretchik, 134-39; Matheny 48-49; Odom, 3748, 239. 
I changed warfare. The 1923 FSR remained the foundational doctrine through most of the interwar period and shaped training and education in army schools. ${ }^{35}$

In 1929, General Charles P. Summerall, Army Chief of Staff, directed revision of the 1923 FSR. The revision, A Manual for Commanders of Large Units (MCLU) (Provisional), Volume 1 - Operations, was highly criticized during its writing. Most criticisms originated from CGSS and the AWC who argued the MCLU borrowed heavily from French doctrine and did not reflect the American way of war represented by the 1923 FSR. Despite the criticisms, the War Department published the MCLU in May 1930 and both manuals remained in army doctrine. Summerall's actions suffered from the enemy is out there and the myth of the management team as he directed publication of the criticized manual despite widespread dissent within the US Army. ${ }^{36}$

Technological developments in tanks, aircraft, and mechanization in the 1930s continued to shift warfare from stable fronts to maneuver. Recognizing this, the Army studied the reorganization and modernization of the infantry division. The War Department estimated a triangular division with 13,500 personnel could replace the square division of 22,000 personnel and retain the same firepower with increased mobility. From 1937 - 1939, the Army conducted experimental field maneuvers to validate this division structure and emerging tactical doctrine. These maneuvers confirmed the study and the Army adopted a triangular division in 1939. The maneuvers and the lessons learned from them helped shape new doctrinal manual, FM 100-5. ${ }^{37}$

${ }^{35}$ FSR 1923, 11, 77; Kretchik, 134-39; Odom 43-46, 130-31.

${ }^{36}$ Kretchik 141-43; Odom, 118-23; A Manual for Commanders of Large Units (Provisional), Volume 1 - Operations (Washington, DC: Government Printing Office, 1930), iii. The WDGS wrote the MCLU for commanders and staffs of divisions and larger units and incorporated doctrine from both the 1923 FSR and France's Provisional Instruction of the Tactical Employment of Large Units, 1921.

${ }^{37}$ Christopher R. Gabel, The U.S. Army GHQ Maneuvers of 1941 (Washington, DC: US Army Center of Military History, 1991), 10-11; Odom, 112-17; Schifferle, 53; United States War 
The contradictory doctrinal manuals, FSR 1923 and the MCLU, forced the War Department, in collaboration with CGSS, to publish FM 100-5 Tentative Field Service Regulations, Operations in 1939. FM 100-5 (1939) retained much of FSR 1923’s doctrine but further stressed combined arms operations, expanded the role of tanks and the air corps in battle, and added mechanized forces. Since the new FM was only a tentative manual, Chief of Staff General George C. Marshall requested comments from field commanders. Additionally, the War Department ordered maneuvers in 1940 to test the new doctrine. ${ }^{38}$

The Louisiana maneuvers conducted in May 1940, coinciding with the German offensive in France, led to Marshall ordering the formation of independent armored forces. Germany’s successes, the Louisiana maneuvers, and criticism of the 1939 FM 100-5 led to the publication of an updated FM 100-5 Field Service Regulations Operations in May 1941. Additional maneuvers in Louisiana and the Carolinas in 1941 validated much of the new doctrine and improved coordination amongst the combat arms. The new doctrine set the foundation for the Army’s training, operations, and materiel procurement through the first three years of World War II. The collaborative approach and use of maneuvers to test new doctrine enabled Marshall and the War Department to overcome the delusion of learning from experience and the myth of the management team. ${ }^{39}$

Department, Annual Report of the Secretary of War (ARSW), 1937 (Washington, DC: Government Printing Office, 1937), 6-7, 34; United States War Department, ARSW, 1938 (Washington, DC: Government Printing Office, 1938), 33-34; ARSW, 1938 (Washington, DC: Government Printing Office, 1938), 28-30; United States War Department, ARSW, 1941 (Washington, DC: Government Printing Office, 1941), 60-61. Although the Regular Army adopted the triangular division structure, the National Guard retained the square division.

${ }^{38}$ Kretchik, 143-48; Odom, 125-30; Field Manual 100-5, Tentative Field Service Regulations, Operations (Washington, DC: Government Printing Office, 1939), 5-7, 15-22.

${ }^{39}$ Gabel, 23-24, 188-92; Field Manual 100-5, Field Service Regulations, Operations (Washington, DC: Government Printing Office, 1941). 
While War Department personnel worked to draw upon the experiences from World War I, they sought to reestablish the schools at Leavenworth and Washington, and reorganize the officer education system with the support of senior officers who had served in the AEF. In March 1919, the WDGS recommended a comprehensive officer education system from precommissioning at West Point through a colonel-level General Staff College. To accomplish this, Pershing directed establishment of a review board to investigate challenges facing the education system after the effects of World War I and make recommendations. ${ }^{40}$

This led to the convening of the McGlachlin Board in February 1922, which examined the entire army school system with emphasis on efficiency due to increased budgetary constraints imposed by the Harding administration (which exceeded even those enacted by the 1920 National Defense Act). The McGlachlin board did not come to consensus on the issues it examined, but its reports still proved very useful. The board submitted to Pershing a majority report, a minority report, and dissenting opinions from McGlachlin and other officers. The majority recommended the School of the Line and the General Staff School combine into a one-year Command and General Staff School, that officers serve not less than two years between education at CGSS and AWC, and no major changes for the AWC. McGlachlin dissented on both reducing the instruction at Fort Leavenworth and the term of service between attendance at CGSS and AWC. Colonel Harold B. Fiske argued in his own minority report that the board poorly delineated the responsibilities of CGSS and the AWC. Due to the various disagreements, Pershing convened a subsequent board, appointing Fiske as its president. ${ }^{41}$

Pershing directed the Fiske board, convened in July 1922, to streamline the officer education system and to delineate the differences between the CGSS and AWC curriculums. The

${ }^{40}$ Harry P. Ball, Of Responsible Command (Carlisle, PA: Alumni Association of the US Army War College, 1984), 180-86; Schifferle, 33.

${ }^{41}$ Schifferle, 33; Ball, 180-86, 194-95. 
board recommended a progressive officer education system from pre-commissioning to the AWC, and designated instruction at the division and corps levels at CGSS and armies and above at AWC. The key features of this education system structure developed by the boards remained in place until mobilization began in 1940 and remains roughly the same today. By convening these boards, Pershing and the War Department demonstrated proactive leadership in trying to establish the right officer education system while remaining open to criticism throughout the process, thus avoiding the myth of the management team. Rather than ignoring or overruling dissent, Pershing convened the Fiske board to resolve the dissenting opinions. ${ }^{42}$

The numerous boards and studies conducted by the WDGS and the Army following World War I established the initial framework for instruction at CGSS and the AWC during the interwar period. Pershing approved the McGlachlin board's majority recommendation to reduce schooling at Leavenworth to a one-year CGSS, followed by a one-year AWC focused on the “strategy, tactics, and logistics of the field army.” Pershing, at the recommendation of the Fiske board, expanded the AWC curriculum to include instruction above the field army level. ${ }^{43}$

Pershing’s framework remained in place until December 1927, when Army Chief of Staff Summerall lengthened instruction at Leavenworth to two years. Before Summerall's decision, Major General Hanson E. Ely, AWC Commandant, chaired a board to consider lengthening the course at CGSS. The board recommended a two-year course as critics argued the shorter course did not provide a sufficient level of instruction for students. Ely dissented in his opinion that the

${ }^{42}$ Schifferle, 33-34; Ball, 194-95.

${ }^{43}$ Ball, 185-86, 194-95. United States Office of the Chairman of the Joint Chiefs of Staff, A Military History of the U.S. Army Command and General Staff College 1881-1963 (Fort Leavenworth, KS: U.S. Army Command and General Staff College, 1964), 22-28. Before Pershing's decision, education at Leavenworth consisted of one year at the School of the Line and a second year at the General Staff School. The School of the Line instructed students on the division and below units while instruction at the General Staff School taught students on corps and army level operations. The reduction to one year also helped eliminate an excess of nearly one thousand students eligible for instruction. 
one-year course could produce more officers even though he saw the benefit from a second year of study. Summerall’s changes reflected McGlachlin's recommendations five years prior. In addition to changes at CGSS, Summerall revised the AWC's mission to train officers on field army level and joint operations, instruct officers on WDGS duties and on the political, economic, and social factors in war, and to study past wars with emphasis on World War I. ${ }^{44}$

In response to these changes to the AWC’s mission, Major General William D. Connor, AWC Commandant, divided the course into two phases: preparation for war and conduct of war. Ball contends that he derived this structure from Carl von Clausewitz's division of war's activities into two categories, “merely preparations for war and war proper.” This two-phased construct lasted until 1940 when preparations for World War II suspended classes. Although the AWC acknowledged its new mission, it appeared the AWC left instruction on the economic, social, and political factors in war to guest lecturers in the subsequent school year. Students attending the AWC also studied the Army’s mobilization plans and its colored war plans for possible contingencies. ${ }^{45}$

Another change to the AWC curriculum occurred in 1934 when General George S. Simonds divided the war plans study into two periods. During the first period, the informative period, students studied mobilization and war plans and theater operations. In the second, formulation of war plans, students revised current war plans and developed additional plans as the world's political environment changed. During the late 1930s, the AWC expanded its curriculum as budget shortfalls and conflict arose around the globe. The AWC added instruction on field

${ }^{44}$ Ball, 210-14; John L. DeWitt, "Orientation, the Army War College Course, 19281929," September 4, 1928, (Military History Institute, AWC Curricular Archives, 1928-1929), 1; Schifferle, 79; United States Office of the Chairman of the Joint Chiefs of Staff, 30.

${ }^{45}$ Ball, 210-14, 245; DeWitt, 1, 7-8; Matheny, 74-78; Carl von Clausewitz, On War, ed. and trans. by Michael Howard and Peter Paret (New York: Alfred A. Knopf, Inc., 1993), 151. Clausewitz explains his classifications of war in Chapter 1 to Book II. 
armies after CGSS reverted to a one-year program in 1935. Additionally, the AWC provided courses on mobilization, foreign relations, and strategy as the United States risked being drawn from continental defense into the spreading conflicts in Europe and Asia. ${ }^{46}$

With the outbreak of World War II in 1939, CGSS accelerated instruction to meet wartime demands for general staff educated officers. In 1940, the War Department suspended instruction at the War College until World War II's hostilities ended. During the interwar period, instruction at both CGSS and the AWC changed frequently due to budgetary constraints, student population needs, and the changing worldwide political environment. Budget constraints and the need to educate enough officers left leadership reacting to these problems and they maintained the illusion of taking charge. Army leadership also overcame this disability as they recognized the changes occurring around the world and shaped instruction to prepare the Army for future conflicts. $^{47}$

Analysis

During the interwar period, the Army sought to create a distinct American way of war from its short-lived experiences on the World War I battlefields. The Army tried to achieve this by capturing its lessons learned and translating them into usable doctrine. General Pershing's emphasis on general staff education persisted through the interwar period and shaped army officer education as it prepared for the next war. Learning disabilities impeded the Army's educational agility.

During this period, the Army, including CGSS and the AWC, experienced the learning disabilities the fixation on events and the illusion of taking charge. While the Army sought to create a doctrine that prepared it for the future, the 1923 FSR retained the Army's pre-World War

${ }^{46}$ Ball, 225-30, 233-40; Matheny, 78-82.

${ }^{47}$ Ball, 257; United States Office of the Chairman of the Joint Chiefs of Staff, 31-33. 
I objective of defeating the enemy through infantry-centric decisive battle. Budget constraints imposed by Congress and the need to meet officer education requirements prevented leadership from being proactive and forced them to react as requirements changed. Pershing's actions as the AEF commander and Army chief of staff contributed the disabilities of the myth of the management team, the enemy is out there, and the delusion of learning from experience as Pershing sought to quell the AEF Superior Board's recommendations and shape the Army in his vision. Additionally, Summerall's actions in publishing FM 100-5 (1939) displayed the same disabilities as Pershing.

While the Army and its schools displayed some learning disabilities, they predominantly exhibited the traits of a learning organization. Beginning with the AEF's review boards in France, the Army applied a collaborative approach to capture lessons learned and translate them into doctrine and education. The Army embraced criticism as it developed the 1923 FSR and convened the Fiske board to adjudicate bottom-up dissent and provide the best recommendations for post-World War I officer education. In the development of the 1939 and 1941 versions of FM 100-5, Marshall and the War Department continued to display the Army's ability to collaborate and accept criticism. The Army leadership also recognized the changing political environment as conflicts arose around the globe and adjusted instruction at the AWC to prepare its senior leaders for World War II.

\section{TRADOC’s Formation to AirLand Battle}

\section{Background}

In the waning years of the Vietnam War, the Army recognized its force structure could

not meet the demand placed on it by the Cold War and the return to a peacetime army following its departure from Southeast Asia. The US Continental Army Command (CONARC) could not both train soldiers and provide forces to support the nation's needs. Operation Steadfast led to the 
dissolution of CONARC and the formation of two distinct organizations: US Army Forces Command and TRADOC. ${ }^{48}$

Department of the Army assigned TRADOC the mission to train individual tactics, techniques, and skills; and develop training procedures and techniques for army units.

Additionally, TRADOC was responsible for developing and writing new concepts and doctrine for the Army and developing the necessary programs of instruction to integrate the new doctrine into education. General William DePuy, with his new headquarters in Fort Monroe, VA had to accomplish this across twenty installations, housing twenty branch and specialized schools, and dozens of Reserve Officer Training Corps detachments across the country. ${ }^{49}$

Less than six months after the creation of TRADOC, the October 1973 Arab-Israeli War provided the catalyst for changes in TRADOC's functional responsibilities, setting the organization on a course that it maintained throughout its first decade. Israel's emphasis on soldiers' weapons proficiency, employment of an elastic defense in the Golan Heights, and its ability to defeat numerically superior forces heavily influenced the 1976 version of FM 100-5, Operations and led to the US Army's increased reliance on weapons and technology. ${ }^{50}$

Narrative

General William E. DePuy assumed command of TRADOC on 01 July 1973. DePuy's experience with Operation Steadfast coupled with his visits to the Army's schools and training centers led DePuy to enact several reforms. DePuy's priorities were to rebalance the schools' training and education, update army doctrine, and integrate combat development with training

${ }^{48}$ Moenk, 33-35; Romjue, Canedy, and Chapman, 5-6.

${ }^{49}$ Moenk, 66, 89; Henry G. Gole, General William E. DePuy: Preparing the Army for Modern War (Lexington, KY: The University Press of Kentucky, 2008), 239; Romjue, Canedy, and Chapman, 6-8.

${ }^{50}$ Brownlee and Mullen, 190-92. 
and doctrine. DePuy sought to accomplish this by relying on the right leaders, developing efficient organizational structures, and creating a means to synchronize TRADOC installations and activities. TRADOC reforms changed how the Army trained and educated its soldiers, noncommissioned officers, and officers, implemented performance-based training, and created the National Training Center at Fort Irwin, California. ${ }^{51}$

After observing several branch school's Officer Basic Courses and Advanced Courses, DePuy set out to change the way the Army branch schools trained and educated their officers. DePuy believed that the "Army had moved pretty much towards education and away from training ... we were totally unbalanced towards education." ${ }^{52}$ DePuy sought to transform the officer education system into one more focused on practical and procedural matters, like focused training to prepare officers for service at company grade. DePuy believed that TRADOC should train junior officers_-particularly platoon leaders and company commanders—in specific tactical skills like how to command a tank, rather than educating them in topics like military history. Leavenworth, DePuy believed, should serve as the institution where officers first received a broader, less tactically focused education..$^{53}$

To resolve these discrepancies and to incorporate new education technologies, TRADOC developed School Model 76. This new organizational model defined the roles of combat developers and training developers within the schoolhouses and required the schoolhouses’ commandants to bridge the gap between combat development and training. Additionally, School Model 76 also prevented instructors from assisting developers, which led to several schools

${ }^{51}$ Gole, 239; Brownlee and Mullen, 186-87; DePuy identified these actions as his most significant accomplishments as the TRADOC commander: rebalancing training and education in the schools, retooling combat development, and updating doctrine.

52 Brownlee and Mullen, 182-83.

${ }^{53}$ Gole, 245, 251-52. 
requesting exceptions to policy to allow integration among the individuals working on these closely related functions. ${ }^{54}$

Since School Model 76 created more problems than solutions, General Glenn K. Otis, TRADOC commander from 1981 to 1983, recommended a new school model. While initially developed to correct the previous version's problems, School Model 83 ultimately took a broader approach, revising the entire TRADOC school model. The new model combined combat development and training development under the same directorate at the schools to integrate their efforts and improve the acquisitions process. Additionally, School Model 83 allowed academic departments to support training development. While the school models were intended to prepare TRADOC for the future, they tended to solve previous problems while also creating new ones. The changing school models exemplify the disabilities the enemy is out there and the fixation on events. ${ }^{55}$

The training and education at the schoolhouses provided the foundation for skills and concepts that needed practice and execution in realistic training centers. However, DePuy was also dissatisfied with the training centers. According to DePuy, "CONARC had run the training centers with an iron hand. Everything that was done in the training centers was prescribed by CONARC. There was no latitude or flexibility, and the first consequence of that was that there was also no feeling of responsibility." DePuy set out to provide commanders and leaders the flexibility to make changes within their organizations to support the TRADOC mission. ${ }^{56}$

${ }^{54}$ Anne W. Chapman, The Army’s Training Revolution 1973-1990: An Overview (Fort Monroe, VA: Headquarters, Training and Doctrine Command, 1994), 7, 20-22; Benjamin King, Victory Starts Here: A 35-year History of the US Army Training and Doctrine Command (Fort Leavenworth, KS: Combat Studies Institute Press, 2008), 39-40.

${ }^{55}$ Chapman, 20-22; King, 40.

${ }^{56}$ Brownlee and Mullen, 183; Gole, 248-49. 
To facilitate these changes DePuy relied on General Paul F. Gorman and the Combat Arms Training Board at Fort Benning who developed the concept of performance-oriented training. Performance-oriented training established training objectives defined from proscribed tasks, conditions, and standards. Their efforts led to the Soldier's Manuals of Common Tasks (SMCT) and the Army Training and Evaluation Program (ARTEP). These standards in training enabled reforms in the schoolhouses and training centers. General Gorman and his team's actions overcame many disabilities including I am my position, the enemy is out there, and the illusion of taking charge. ${ }^{57}$

While the ARTEP created the foundation for how the Army trains through the present, its initial design allowed for subjective evaluation of the training standards. In response, TRADOC initiated several training studies to identify problems and recommend solutions, such as the 1978 Review of Education and Training of Officers, known as the Harrison board. Reiterating CGSC's purpose to train and educate officers in combined arms units, high-level staff, and resource and training management, the Harrison board recommended pre-commissioning standards and Military Qualification Standards for all officers up to the tenth year of service, creation of a Combined Arms and Services Staff School for all active and reserve component officers, and updates to CGSC and AWC curricula. The board also recommended a reduction in the annual number of CGSC students, but continuation of the Master of Military Arts and Science (MMAS) and cooperative degree programs, and expansion of the electives program. These recommendations resembled those published by 1971 Norris board. Congress subsequently authorized the MMAS program in 1974 and the program received accreditation in $1976 .{ }^{58}$

${ }^{57}$ Brownlee and Mullen, 184-85; Gole, 249-51.

${ }^{58}$ Benjamin L. Harrison, A Review of Education and Training for Officers, vol. 2, Career Progression (Washington, DC: Headquarters, Department of the Army, 1978), E-1-3-E-1-5, E-43, E-4-6, E-4-12; Frank Norris, "Review of Army Officer Education System, Volume 1, 
The Harrison board identified a gap in corps-level doctrine and education at CGSC and the AWC. The Harrison board recommended that the AWC adjust its curriculum to close this gap until TRADOC published updated doctrine. Additionally, the board recommended AWC update its mission to reflect the US Army's wartime mission: "the integrative aspects of joint and combined land warfare operations” and revise the curriculum to reflect the US Army's mission, objectives, and guidance provided by Headquarters, Department of the Army. The Harrison board attempted to realign instruction at CGSC and the AWC to meet Army requirements and provide education equivalent to civilian post-graduate institutions. The continued use of boards to evaluate instruction and the Army's educational institutions reflected acceptance of criticism and avoidance of the myth of the management team..$^{59}$

When DePuy assumed command of TRADOC General Donn A. Starry commanded the US Army Armor Center and School at Fort Knox, Kentucky. Starry knew the German Army trained at Hohenfels and Grafewoehr to practice maneuver and long-range weapons qualification. Starry believed the US Army needed a similar training center to hone maneuver skills.

Additionally, Gorman advocated for a combined arms training center at Ft. Irwin, California. Gorman argued increased weapons range and firepower, greater mobility, and the need to train as it fights, the Army required a large maneuver area to conduct realistic training. Their efforts led to the first battalions trained at the National Training Center (NTC) at Fort Irwin, California in 1981. The generals' efforts to link training with doctrine and capabilities showed vision and

Summary Report” (Fort Leavenworth, KS: Combined Arms Research Library, 1971), 6-5; Bankston, 24-28; James D. Sisemore, "Fort Leavenworth and its Education Legacy; Recommendations for ILE” (Monograph, US Army Command and General Staff College, 2012), 44-45; Chapman, 11-13; Benjamin L. Harrison, A Review of Education and Training for Officers, vol. 1, An Overview (Washington, DC: Headquarters, Department of the Army, 1978), XI-1-XI9; Edward B. Bankston, "Boards versus Bureaucracies: Field Grade Officer Education in the United States Army, 1946-1985” (Monograph, US Army Command and General Staff College, 2013), 28-36.

\footnotetext{
${ }^{59}$ Harrison, Career Progression, F-1-8-F-1-9, F-1-32-F-1-35.
} 
action beyond their positions, and depicted proactive action, thus overcoming the disabilities I am my position and the illusion of taking charge. ${ }^{60}$

While DePuy worked to update training and education, he also worked to integrate them with combat development projects that, in the early 1970s, focused on concepts derived from current platforms using forecasted technological improvement to create weaponry for 1990-2000. DePuy sought to bring realism into the development approach to provide credible capabilities to the warfighter.

DePuy observed that combat development and concepts were a circular and feedback intensive process involving researchers, developers, and end users. Technological developments led to the application of technology in weapons systems, which then led to concepts for employment. During the 1970s and 1980s, TRADOC developed several new combat systems to fight the Warsaw Pact. The five primary systems served as symbols of the new Army doctrine: the Abrams tank, the Bradley infantry fighting vehicle, the Patriot missile system, and two new helicopters (the UH-60 Blackhawk and AH-64 Apache). DePuy believed combat development spent too much time conducting long-range studies in the 1970s focused on how the Army would look in the 2000s. DePuy cancelled most studies and refocused combat development on shorterrange improvements to existing equipment. This fixation on events brought short- and mid-term solutions that created the Army's primary weapon systems though the start of the $21^{\text {st }}$ century but left the Army with no long-term combat development goals. ${ }^{61}$

Procurement and employment of these weapon systems factored heavily in the development of DePuy's third priority, updating Army doctrine. DePuy felt the current doctrine focused too heavily on principles and the philosophy of warfare, and that doctrine should tell

${ }^{60}$ Chapman, 9-10, 19; Gole, 247; Paul F. Gorman, “Toward a Combined Arms Training Center,” Speech at TRADOC Conference, Fort Monmouth, NJ, November 9, 1976.

${ }^{61}$ Brownlee and Mullen, 181; Gole, 254-57. 
commanders how to fight. In 1976, TRADOC published FM 100-5 Operations, which created new Army doctrine that both provided proscriptive guidance and suited the operations of a mechanized army operating in Europe rather than a light army operating in Vietnam. ${ }^{62}$

DePuy and his team sought to develop doctrine that taught the Army how to fight by matching weapons capabilities with the enemy threat and finding ways to defeat the enemy with available weapons and tactics. Current weapons capabilities, the military-political situation in Germany, and the 1973 Arab-Israeli War influenced this new doctrine. Germany desired a forward defense posture; however, the Army developed the compromise solution of on active defense to defeat the Soviet threat. ${ }^{63}$

DePuy sought to simplify doctrine by eliminating theory and providing practical solutions for the challenges of combat. Major General Jack Cushman, Combined Arms Center (CAC) Commander at Fort Leavenworth, disagreed with this approach. Cushman and his staff at CAC, originally responsible for writing FM 100-5 resisted DePuy’s concept in favor of a more conceptual and theoretical approach. In response to Cushman's criticisms, DePuy assigned the task of writing FM 100-5 to a small group of selected officers at Fort Monroe. This small group of officers, collectively known as the “Boathouse Gang,” wrote FM 100-5 precisely as directed by DePuy. The Boathouse Gang exemplified Senge’s concepts of the myth of the management team, the illusion of taking charge, and the enemy is out there as DePuy sought to avoid any criticism toward his capstone doctrinal publication. Additionally, by creating a stove piped method for doing the work, DePuy displayed the disability of the delusion of learning from experience. ${ }^{64}$

${ }^{62}$ Gole, 257-66; Field Manual 100-5, Operations (Washington, DC: Government Printing Office, 1976).

${ }^{63}$ Brownlee and Mullen, 187-92.

${ }^{64}$ Gole, 258-60, 265. 
FM 100-5 (1976) had its detractors before publication and the Army soon rejected it. FM 100-5's development consisted almost solely of DePuy's select group and had little consensus or support throughout the Army. The critics of FM 100-5 (1976) argued that the manual overemphasized firepower and the defense, rejecting the Army's traditional emphasis of offensive maneuver. Additionally, its critics argued that the manual focused too much on weapons and tactics, and too little on concepts. Lastly, FM 100-5’s critics argued active defense required yielding German territory to the Soviet Union to provide time for the US Army to build up its defenses. ${ }^{65}$

The broad discussion that developed from FM 100-5's publication led to General Starry, as the TRADOC commander, ordering the rewrite of FM 100-5. The 1982 publication became known as AirLand Battle. A major step in US Army doctrine development, AirLand Battle added the operational level of war to the American battlefield and sought to employ maneuver and deep attacks to disrupt the enemy before engagement in the main battle area. Starry and other leaders saw deep attacks against the Soviet's second echelon as a means to resolve the issue of yielding terrain to the Soviet attack. AirLand Battle added the tenets of initiative, depth, agility, and

65 John L. Romjue, American Army Doctrine for the Post-Cold War (Fort Monroe, VA: Headquarters, Training and Doctrine Command, 1993), 16-20; Donn A. Starry, "To Change an Army," Military Review 63, no. 3 (March 1983): 24-25; For criticisms of FM 100-5 see Donald K. Griffin, “If the Soviets Don't Mass,” Military Review 59, no. 2 (February 1979): 54-65; William S. Lind, "Some Doctrinal Questions for the United States Army," Military Review 57, no 3 (March 1977): 54-65; John M. Oseth, "FM 100-5 Revisited: A Need for Better 'Foundation Concepts’?” Military Review 60, no. 3 (March 1980): 2-12; For FM 100-5’s supporters see: Archer Jones, “The New FM 100-5: A View From the Ivory Tower,” Military Review 58, no. 2 (February 1978): 27-36; Dan G. Loomis, "FM 100-5 Operations: A Review,” Military Review 57, no. 3 (March 1977): 66-69; Donn A. Starry, “A Tactical Evolution - FM 100-5,” Military Review 58, no. 8 (August 1978): 2-11. FM 100-5 did have supporters because it refocused the Army and provided a way ahead as it sought to move forward following the Vietnam War. 
synchronization to describe how the Army fights while adopting an American interpretation of the German Army’s concept of Auftragstaktik to allow commanders tactical flexibility. ${ }^{66}$

Because of the opposition to the Active Defense manual, instructors within the Department of Tactics at CGSC wrote AirLand Battle. Additionally, AirLand Battle reflected the debates centered on the inadequacies found in Active Defense and incorporated recommendations from the force. The 1982 revision of FM 100-5 displayed TRADOC overcoming the myth of the management team and the delusion of learning from experience to provide a doctrine that utilized a team effort and considered criticisms from the 1976 version. ${ }^{67}$

Analysis

From its creation to the production of AirLand Battle, TRADOC led the Army's transformation from a disjointed service searching for its identity following the Vietnam War to a revitalized Army with sound doctrine, improved weapon systems, and a training and education system that prepared the Army for future conflicts. Inherent learning disabilities hindered TRADOC’s progress and limited its agility.

During this period, TRADOC suffered from the disabilities the enemy is out there, the fixation on events, and the illusion of taking charge. The shifting and evolving school models and

${ }^{66}$ Romjue, American Army Doctrine for the Post-Cold War, 19-20; FM 100-5 (1982), 21-2-3; Robert M. Citino, The German Way of War: From the Thirty Years' War to the Third Reich (Lawrence, KS: University Press of Kansas, 2005), 307-12. Citino argued that the US military misunderstands Auftragstaktik. The US military defined Auftragstaktik as the commander devising the mission and leaving its details to subordinate commanders as long as they stayed within the commander's intent. According to Citino, this definition amounts to mythology and he pointed out that Germans officers rarely used the term in reference to command methods, instead using it to emphasize a subordinate commander's independence from higher echelon command. Citino also pointed out that Auftragstaktik did not fit well with the realities of warfare that modern militaries faced, putting it simply: "An army group is too precious a national asset to entrust to the whims of one man." The romanticized version of the term as used in the $1982 \mathrm{FM}$ 100-5, Operations remains a common misperception among military practitioners and historians.

${ }^{67}$ Romjue, American Army Doctrine for the Post-Cold War, 20; Starry, “To Change an Army," 24-27. 
DePuy's changes to combat development provided short-term fixes for TRADOC, but they did not provide long-term solutions. These actions, combined with DePuy’s reluctance to listen to those with differing opinions in writing FM 100-5 and his reliance on the "Boathouse Gang” indicated an organization that suffered from reactiveness and had a culture of focusing on external blame for internal problems.

While TRADOC exhibited several learning disabilities, it also showed either the traits of a learning organization or the ability to overcome disabilities. General Gorman's efforts at Fort Benning and AirLand Battle’s publication in 1982 provide examples of this. Gorman, along with Starry, could see beyond their positions in TRADOC and provide solutions for not only TRADOC, but also the Army. The creation of the SMTC and ARTEP, along with the establishment of NTC at Ft. Irwin, California provided the framework for how the Army still trains and evaluates today.

\section{Historical Case Synthesis}

These case studies provide historical analysis of TRADOC during the post-Vietnam War era and similar army institutions during the interwar period, and provide the foundation for the final case study of TRADOC. Comparative analysis using Senge’s learning disabilities identifies similarities and trends in the US Army's and TRADOC's headquarters and education systems that span historical periods and may apply to TRADOC today. These organizations displayed both learning disabilities and the ability to overcome them.

The organizations examined in both case studies suffered from five out of seven of Senge’s learning disabilities. External pressures and changing environments caused organizations and individuals to build defensive barriers to criticism and shift blame to others as they failed to see the impact of their actions on the system. Pershing's insistence on shaping the post-World War I army in his vision and the constant adjustments to school missions and models in both case studies displayed the enemy is out there disability. 
These environments created the perception within the organizations that changes needed to be made to prepare for future uncertainties. However, while those making these changes thought they were being proactive, instead they were reacting to problems in the system. This illusion of taking charge led to reactionary changes in the school systems. Coupled with this reactiveness, these organizations tended to become fixated on events that recently occurred. Doctrine development following major conflicts tends to resemble the last conflict like the 1923 FSR. Additionally, changes to processes, while they produce short-term results, can yield longterm deficiencies as DePuy’s changes to combat development.

Leaders in the organizations also exhibited Senge's learning disabilities the delusion of learning from experience and the myth of the management team. When Pershing and DePuy assumed command of their organizations, they created or modified the organizations to suit their needs/desires and assigned select personnel to them. This created stovepipes within their organizations and insulated them from differing opinions and criticism. Pershing's resistance to the AEF Superior Board's recommendations and his realignment of the WDGS as Chief of Staff, Summerall's publication of FM 100-5 (1939), and DePuy’s “Boathouse Gang” as they wrote FM 100-5 (1976) exemplified these disabilities.

The changing environments and rapid pace these organizations operated at exhibited a sixth learning disability, the parable of the boiled frog. This disability stems from the illusion of taking charge and the fixation on events. Due to changing leadership and organizations' desires to fix things and make changes, often the solutions provided short-term resolutions that prevented the organizations from examining the underlying gradual changes. The Army’s frequently changing doctrine and school systems illustrate this. Although inherent learning disabilities existed in both case studies, the army and TRADOC also showed the qualities of a learning organization as they overcame or avoided Senge’s learning disabilities. 
Pershing's directives to capture the AEF's lessons learned from the World War I battlefields and his insistence on creating a well-trained and educated general staff though the officer education system helped instill a learning culture within the army. The numerous review boards conducted by the AEF during the interwar period and though TRADOC's early years avoided learning disabilities. Additionally, these boards showed the army and TRADOC could, when examining recent events, look to the future and provide proactive recommendations. By their nature and organization, the board helped prevent stove piping and facilitated collaboration between army organizations.

During these periods, review boards and Army officers criticized TRADOC, the WDGS, and/or their actions. Frequently the Army and TRADOC welcomed these criticisms and applied them as exemplified by the writing of the 1923 FSR and the 1982 and 1941 versions of FM 1005. This would not have been possible without leaders such as Pershing, Marshall, Starry, and Gorman who acknowledged the critics and facilitated a collaborative and learning culture.

Comparative historical case analysis indicates the Army and TRADOC consistently experience Senge’s learning disabilities. Although these disabilities persisted through the $20^{\text {th }}$ century, Army leadership and a culture of learning mitigated their influence and enabled the Army to adapt and prepare for future conflicts. These two case studies provide the foundation for the final case study of TRADOC.

\section{TRADOC Today}

\section{Background}

The terrorist attacks on September 11, 2001 started a new period in American military history. At this time, the Army was transitioning its doctrine to encompass the AirLand Battle successes in Operations Desert Shield and Desert Storm and lessons learned from operations other than war conducted in Operation Restore Hope, Rwanda, and the Balkans. The new doctrine, FM 3-0 Operations, published months before the attacks, sought to integrate these 
experiences into full-spectrum operations that combined the concepts of offense, defense, stability, and security operations. ${ }^{68}$

Within 18 months after the terrorist attacks, the US Army was engaged in two conflicts in Iraq and Afghanistan. Both Operations Enduring Freedom (OEF) and Iraqi Freedom (OIF) succeeded beyond initial expectations and appeared to validate FM 3-0 (2001). While the army in OIF appeared successful during the conventional warfare phase of operations, the environment in Iraq transitioned from conventional war to an insurgency (although senior American political and military leaders argued that the conflict had not evolved into an insurgency). Meanwhile, TRADOC sought to provide the means to succeed in this different type of war. ${ }^{69}$

Narrative

In 2007, General William Wallace, TRADOC Commander, directed an update of FM 30. The CAC Commander, Lieutenant General William B. Caldwell IV, led a team that used a collaborative approach to update the Army's operational doctrine. The new FM 3-0, published in 2008, drew from multiple sources including the Army’s experiences in Afghanistan and Iraq, concepts that appeared in FM 3-24 Counterinsurgency in 2006, and comments from the field. The authors of Operations declared it revolutionary in that it recognized that "current conflicts defy solution by military means alone and that landpower, while critical, is only part of each campaign. Success in future conflicts will require the protracted application of all the instruments of national power.” Along this vein, FM 3-0 depicted stability and civil support operations equal to offensive and defensive operations. The collaborative approach to writing, like that used in the

${ }^{68}$ Bill Benson, "Unified Land Operations: The Evolution of Army Doctrine for Success in the $21^{\text {st }}$ Century,” Military Review 92, no. 2 (March-April 2012): 3-8; Kretchik, 232-60.

${ }^{69}$ Ali A. Allawi, The Occupation of Iraq: Winning the War, Losing the Peace (New Haven, CT: Yale University Press, 2007), 163-90; Kretchik, 260-63. 
development of the 1929 FSR, indicates TRADOC avoided the disabilities of the delusion of learning from experience and the myth of the management team. ${ }^{70}$

In 2011, TRADOC published an update to FM 3-0 and eight months later published the Army’s current capstone doctrine, Army Doctrine Publication (ADP) 3-0 Unified Land Operations (ULO). In his forward, General Raymond T. Odierno wrote that ULO built upon AirLand battle and full-spectrum operations. ADP 3-0 introduced two new core competencies as the means by which the Army would integrate all warfighting functions across offense, defense, and stability operations. Despite the characterization by some of the new doctrine as revolutionary, Colonel Bill Benson, part of the writing team, argued that the new ADP 3-0 contains some new terminology, but the central concepts remain essentially unchanged since AirLand Battle. ${ }^{71}$

ADP 3-0's publication reverberated through the Army as the field sought to understand the new terminology and concepts. Its critics called it a missed opportunity while its supporters called ADP 3-0 a chance for the future. Major J.P. Clark, an Army strategist at Headquarters, Department of the Army, criticized ADP 3-0 for poorly addressing the current operational environment's complexity, being too theoretical without providing example case studies as previous doctrine did, and for lacking the details required to understand its concepts and terms. Clinton Ancker, director of the Combined Arms Doctrine Directorate at CAC, and Michael Scully, a doctrine writer at CAC, sought to refute Clark and argue that ADP 3-0, as the foundation of Doctrine 2015, provides an opportunity for the Army to look to the future. Ancker and Scully argued that Doctrine 2015’s commonality and brevity would actually serve as

${ }^{70}$ Field Manual 3-0, Operations (Washington, DC: Government Printing Office, 2008), vii-viii; Kretchik, 269-77; Benson, 7-8.

${ }^{71}$ Army Doctrine Publication 3-0, Unified Land Operations (Washington, DC: Government Printing Office, 2011), Foreword, 5; Benson, 8-12. 
strengths by enabling a greater shared understanding across the force. Additionally they contended that subsequent Army Doctrine Reference Publications would provide the details that Clark believed absent from the ADP, and they pointed out that current doctrine development is a collaborative process used to generate consensus among Army leaders. By using a collaborative approach to ADP 3-0's publication, TRADOC avoided the myth of the management team disability; however, the ADP's revolutionary brevity and departure in structure from previous Army doctrinal publications created the perception of ADP 3-0 as a top-down guided product and the idea that TRADOC suffered from the delusion of learning from experience. ${ }^{72}$

As the conflict in Iraq both expanded and shifted from conventional to counterinsurgency (COIN) warfare in 2004 and 2005, the Army deployed units assigned to the Combat Training Centers (CTC) at NTC and the Joint Readiness Training Center at Fort Polk, Louisiana to relieve the pressure created by repeated unit deployments. These deploying units served as the opposing forces for units training at the Army's CTCs. Their knowledge of the terrain at the CTCs combined with their experience practicing US Army doctrine in simulated combat during multiple training rotations made these units some of the best-trained US Army forces deployed to Iraq and Afghanistan. While the Army deployed these units to gain experience in COIN warfare, some authors argued against deploying them because this would reduce the quality of training at CTCs. These deployments coincided with changes made to the training at the CTCs, including additional emphasis on COIN related tasks and scenarios. This made the deployment of the CTC personnel a valuable investment in the current relevance of the training centers. ${ }^{73}$

72 J.P. Clark, "The Missed Opportunity: A Critique of ADP 3-0, Unified Land Operations,” Military Review 92, no. 4 (July-August 2012): 46-52; Clinton J. Ancker and Michael A. Scully, "Army Doctrine Publication 3-0: An Opportunity to Meet the Challenges of the Future,” Military Review 93, no. 1 (January-February 2013): 38-42.

${ }^{73}$ Frederick W. Kagan, “The Incredible Shrinking Army,” Weekly Standard 9, no. 35 (May 24, 2004): 14-15; Roxana Tiron, “Army Still Needs World-Class 'Red Force’ in Training 
Before OIF and OEF, Army units fought a near-peer force styled after the Soviet Union. As the conflicts in Iraq and Afghanistan continued, the Army transformed the training at its CTCs to combat an insurgent force instead of a combined arms maneuver forces. The transition meant to replicate the combat in Iraq and Afghanistan opposed to the Cold War era enemy fought before OIF. Although the transition made the CTCs better prepared to train units to fight in the conditions prevalent in OEF and OIF, some authors argued the overemphasis of COIN training at the CTCs reduced the Army’s ability to conduct other operations. COIN-focused training continued at the CTCs until the Army's drawdown in Iraq. ${ }^{74}$

Training at the Army’s CTCs changed again in 2011 and 2012 as the Army sought to rebalance the force and update the training it received. The anticipated conclusion of COIN operations in Iraq at that time led the Army to reconsider the training conducted at its CTCs. This began with publication of Training Circular (TC) 7-100, Hybrid Threat in November 2010. TC 7100 described the Army’s new enemy threat model against which its units would train. Combined with the publication of ADP 3-0, TC 7-100 indicated a shift in the Army's focus from fighting COIN to fighting an enemy that may combine both conventional and unconventional means to fight US forces. ${ }^{75}$

This transition manifested in the application of the hybrid threat model at the CTCs and Army units executing decisive action through combined arms maneuver and wide area security to

Centers,” National Defense 89, no. 613 (December 2004): 40.

${ }^{74}$ Dennis Steele, “Decisive-Action Training Rotations: 'Old School Without Going Back in Time',” Army 63, no. 2 (February 2013): 26-27; Gian P. Gentile, "Let’s Build an Army to Win All Wars,” Joint Force Quarterly 52 (First Quarter 2009): 31-33; Chad C. Serena, Revolution in Military Adaptation: The US Army in the Iraq War (Washington, DC: Georgetown University Press, 2011), 2-6, 168-73.

${ }^{75}$ Steele, 31-32, 36; "A hybrid threat is the diverse and dynamic combination of regular forces, irregular forces, and/or criminal elements all unified to achieve mutually benefitting effects.” Training Circular 7-100, Hybrid Threat (Washington, DC: Government Printing Office, 2010), v. 
defeat varied threats. The first NTC unit rotation to apply this threat construct took place in March 2012. Today, units at the CTCs face a range of threats from a near-peer enemy, insurgents, and criminal groups, to include cyber threats. The current training at the CTCs reflects a proactive understanding of the Army's needs beyond its most recent combat experiences and demonstrates that the Army avoided the disabilities of the illusion of taking charge and the fixation on events. ${ }^{76}$

In 2004, the Army made a significant change to field grade instruction, eliminating the longstanding policy of selecting only the top $50 \%$ of officers in each year group to attend the CGSC resident course in favor of 100\% attendance at Intermediate Level Education (ILE) at CGSC or a satellite course. The Army based this decision on the recommendations of the Army Training and Leader Development Panel Officer Study conducted in 2000 to increase the number of educated officers. The new ILE curriculum contained adjustments intended to enable officers to work in complex environments, think critically, and prepare for battalion command and highlevel staff duty. ${ }^{77}$

The increased operational need for field grade officers during OEF and OIF created a backlog of officers needing to attend ILE. Commanders allowed officers to defer attendance or prevented officers from attending due to combat requirements. These actions reduced active duty officer attendance at ILE and led to the backlog. This existed until the Army decided in 2012 to revamp ILE attendance by expanding ILE opportunities. Per Army Directive 2012-21, officers today attend ILE at a 10-month resident course at CGSC, at 14-week satellite campuses, and distributed learning. During the transition, the Army provided constructive credit waivers for

${ }^{76}$ Steele, 31-37; David Crozier, "Decisive Action: How to Fight and Sustain in the Army’s Future Battles,” NCO Journal, May 28, 2013, accessed March 26, 2015, http://ncojournal.dodlive.mil/2013/05/28/decisive-action-how-to-fight-and-sustain-in-the-armysfuture-battles/.

${ }^{77}$ Sisemore, 57-59; Thomas S. Hollis, “ILE a Casualty of War” (Monograph, US Army Command and General Staff College, 2008), 18-19; Neal Bralley et al., "Understanding ILE: How is it Different from CGSOC?” Special Warfare 16, no. 3 (February 2004): 32-34. 
officers who completed key developmental positions to help reduce the backlog. The Army’s decision to provide ILE to all field grade officers was proactive and avoided the illusion of taking charge; however, the Army also suffered from this disability as it reacted to operational needs and became fixated on events both in its creation of the backlog and its attempts to eliminate it. $^{78}$

Today, the AWC differs from its origins in the $20^{\text {th }}$ century and during the interwar period when it prepared officers for general staff positions and educated them on preparation and execution of war plans. The AWC currently identifies its purpose as the production of "graduates from all our courses who are skilled critical thinkers and complex problem solvers in the global application of Landpower,” and it identifies itself as a “"Think Factory” for Commanders and Civilian Leaders at the strategic level worldwide.” Its critics argue the AWC resembles an Army version of civilian graduate-level education programs while its proponents argue this type of education benefits the Army and AWC graduates. ${ }^{79}$

In 2007, General David H. Petraeus, Commander of Multi-National Force - Iraq, argued for Army officers to attend civilian graduate programs and for army schools to have the equivalent rigor he experienced completing his graduate degrees. Ralph Peters disagreed and argued that the Army does not need intellectual officers but those with experience who can act decisively. This debate regarding the overall purpose of the AWC continues as the Army seeks

${ }^{78}$ Hollis, 26-29; Office of the Chief of Public Affairs, “Army Announces Optimization of Intermediate Level Education,” www.Army.mil, September 24, 2012, accessed March 26, 2015, http://www.army.mil/article/87406; John M. McHugh, Army Directive 2012-21 Optimization of Intermediate-Level Education (Washington, DC: Government Printing Office, 2012); TRADOC Pamphlet 350-70-12, The Army Distributed Learning (DL) Guide (Fort Eustis, VA: Headquarters, Training and Doctrine Command, 2013), 8-9. Distributed learning provides training and education through online interaction between students, instructors, and facilitators.

${ }^{79}$ Army War College, “About the US Army War College,” AWC, accessed March 26, 2015, http://www.carlisle.army.mil/overview.htm; Robert E. Petty, “Training vs. Education at the Army War College: The Benefits of a Return to the Past” (Monograph, US Army Command and General Staff College, 2014), 42. 
the optimal curriculum in each of its key institutions to establish the optimal balance for its officers’ education. ${ }^{80}$

Analysis

Today, TRADOC leads the Army as it responds to national policy guidance that directs it to transform from a force fighting two COIN conflicts in Iraq and Afghanistan to one that is prepared to respond to worldwide contingencies. Like the previous case studies, learning disabilities hindered TRADOC's progress; however, TRADOC also continued to exhibit the attributes of a learning organization. During this period, the disabilities, the fixation on events, the illusion of taking charge, and the delusion of learning from experience hindered TRADOC.

The perception that ADP 3-0 was a top-down guided product created the illusion that TRADOC suffered from the delusion of learning from experience. Both the Army's and TRADOC's changes to training at the CTCs, and education at ILE and the AWC resembled an organization that reacted to recent events opposed to preparing for future uncertainties. The disabilities of the illusion of taking charge and a fixation on events hindered TRADOC as it reacted to operational needs.

While TRADOC exhibited several learning disabilities, it also showed either the traits of a learning organization or the ability to overcome disabilities. TRADOC avoided the disabilities the illusion of taking charge and the myth of the management team. TRADOC's collaborative writing of FM 3-0 (2008) and ADP 3-0 avoided the disabilities of the delusion of learning from experience and the myth of the management team. Although the changes to training at the CTC's

${ }^{80}$ Petty, 42; David H. Petraeus, “To Ph.D. or Not to Ph.D....” American Interest 2, no. 6 (July/August 2007): 16-20; Ralph Peters, “Learning to Lose,” American Interest 2, no. 6 (July/August 2007): 20-28; George E. Reed, "What’s Wrong and What's Right With the War Colleges,” Defense Policy Journal, July 1, 2011, accessed March 26, 2015, http://www.defensepolicy.org/george-reed/what\%E2\%80\%99s-wrong-and-right-with-the-warcolleges. 
and education at ILE were reactive and focused on recent events, the current training and education appear to overcome the disability of the illusion of taking charge as TRADOC and the Army look to prepare for future conflicts.

\section{Conclusion}

Today, as the United States continues its drawdown in Afghanistan and seeks solutions to continued and developing unrest in the world, TRADOC works to provide the US Army the right doctrine, training, and education. Current budgetary constraints will continue to restrict TRADOC's solutions as the United States tries to resolve its fiscal responsibilities. Comparative analysis of TRADOC today with the historical cases indicates similarities between today and the past.

Senge’s learning disabilities the illusion of taking charge, fixation on events and the delusion of learning from experience persisted from the interwar period to today. Often, writers argue that an army prepares for the last war it fought. These disabilities, and the pitfalls the Army and TRADOC fell into align closely to this argument. Experiences in the trench lines of France, the jungles of Vietnam, and the cities and deserts of OIF influenced the training and education created, and the doctrine written following those conflicts.

The transition to COIN training at the CTCs also exemplifies this preparation for fighting the previous (or current) war unlike the Louisiana maneuvers in the 1930s and 1940s, and the creation of the CTCs in the 1980s. Before OIF/OEF, the Army did not anticipate conducting a large-scale COIN fight and did not prepare for one until fully committed. During the interwar period, the Army started modernizing and conducted large unit exercises to validate doctrine, organizations, and modernization. The training that led up to the Louisiana Maneuvers prepared the Army to fight the war it ended up fighting in World War II.

Army leadership can exhibit or create the perception of exhibiting the learning disabilities the delusion of learning from experience and the myth of the management team. Publication of 
ADP 3-0, like the publication of FM 100-5 in 1939 and 1976, created a strong reaction from the field. Critics and supporters alike spoke out as they tried to understand and embrace the new doctrine. If history proves anything, the next major conflict the United States enters will provide a definitive test of the value of ADP 3-0, decisive action training against a hybrid threat at the CTCs, and the civilianizing of education at CGSC and the AWC to prepare today's US Army for the next war.

Implications

The Army must always seek to anticipate future conditions and establish the best and most appropriate training and education programs and facilities possible to deal with likely future contingencies. The Army always should think about the next war, refusing to accept the easy but dangerous delusion that the next war will resemble the last. In his determination to not fight another Vietnam, DePuy led TRADOC to shape the Army in accordance with his vision of the war the Army should fight, the 1973 Arab-Israeli War. FM 100-5 (1976) and the weapon systems developed to execute this new operational doctrine tailored the Army to fight the Soviet Union in Europe, but this war never took place despite the specificity of the threat the Soviet Union represented. The Army Capstone Concept, Army Operating Concept, and ADP 3-0 serve as an integrated expression of Army concepts and doctrine that will enable the transformation of TRADOC into an adaptable organization; however, TRADOC must remain vigilant, identifying Senge’s learning disabilities wherever they might appear and always working to avoid or overcome them.

Only through such vigilance and self-critique can TRADOC prepare for the next war as effectively as the US Army did in the interwar years, despite the many obstacles it faced. Current trends indicate a development process more like that guided by DePuy in the aftermath of the 1973 Arab-Israeli War. This undeniably led to an Army that possessed the equipment, training, and doctrine it required to perform at the operational level, but against a threat that failed to 
materialize. Perhaps most important lesson the Army can learn from this period is that it proved ill-suited to conduct operational art in conditions that differed significantly from those DePuy envisioned. Given the nation's poor record of predicting the nature of the next war, the US Army must remain operationally adaptive and agile so that it can respond appropriately to the range of threats that it could face in the next war. 


\section{Bibliography}

A Manual for Commanders of Large Units (Provisional), Volume 1 - Operations. Washington, DC: Government Printing Office, 1930.

Allawi, Ali A The Occupation of Iraq: Winning the War, Losing the Peace. New Haven, CT: Yale University Press, 2007.

American Expeditionary Force. Combat Instructions. General Headquarters American Expeditionary Force, 1918.

Ancker, Clinton J. and Michael A. Scully. “Army Doctrine Publication 3-0: An Opportunity to Meet the Challenges of the Future.” Military Review 93, no. 1 (January-February 2013): 38-42.

Argyris, Chris and Donald A. Schön. Organizational Learning: A Theory of Action Perspective Reading, MA: Addison-Wesley Publishing Company, 1978.

Army Doctrine Publication 3-0, Unified Land Operations. Washington, DC: Government Printing Office, 2011.

Army Doctrine Publication 6-22, Army Leadership. Washington, DC: Government Printing Office, 2012.

Army Doctrine Reference Publication 6-22, Army Leadership. Washington, DC: Government Printing Office, 2012.

Army War College. “About the US Army War College.” Army War College. Accessed March 26, 2015. http://www.carlisle.army.mil/overview.htm.

Bailey, Jonathan B. A. “The First World War and the Birth of Modern Warfare.” In The Dynamics of Military Revolution: 1300-2050, edited by MacGregor Knox and Williamson Murray. New York: Cambridge University Press, 2001.

Ball, Harry P. Of Responsible Command. Carlisle, PA: Alumni Association of the US Army War College, 1984.

Bankston, Edward B. "Boards versus Bureaucracies: Field Grade Officer Education in the United States Army, 1946-1985.” Monograph, US Army Command and General Staff College, 2013.

Benson, Bill. "Unified Land Operations: The Evolution of Army Doctrine for Success in the $21^{\text {st }}$ Century.” Military Review 92, no. 2 (March-April 2012): 2-12.

Blankenhagen, Edward E. "Organizational Learning in the Development of Doctrine in the U.S. Army, 1976-1986: A Historically-Based Study.” Doctoral Dissertation, The George Washington University, 1994.

Bralley, Neal, Jim Danley, Dan French, Chuck Soby, and Paul Tiberi. "Understanding ILE: How is it Different from CGSOC?” Special Warfare 16, no. 3 (February 2004): 32-34.

Bronfeld, Saul. "Did TRADOC Outmanoeuvre the Manoeuvrists? A Comment.” War \& Society 27, no. 2 (October 2008): 111-125.

Brownlee, Romie L. and William J. Mullen, III. Changing an Army: An Oral History of General William E. DePuy, USA Retired. Carlisle Barracks, PA: United States Military History Institute, 1987. 
Calhoun, Mark T. “Complexity and Innovation: Army Transformation and the Reality of War.” Monograph, US Army Command and General Staff College, 2004.

Chapman, Anne W. The Army's Training Revolution 1973-1990: An Overview. Fort Monroe, VA: Headquarters, Training and Doctrine Command, 1994.

Citino, Robert M. The German Way of War: From the Thirty Years' War to the Third Reich. Lawrence, KS: University Press of Kansas, 2005.

Clark, J.P. “The Missed Opportunity: A Critique of ADP 3-0, Unified Land Operations.” Military Review 92, no. 4 (July-August 2012): 46-52.

Clausewitz, Carl von. On War. Edited and translated by Michael Howard and Peter Paret, New York: Alfred A. Knopf, Inc., 1993.

Cooke, James J. Pershing and His Generals: Command and Staff in the AEF. Westport, CT: Praeger, 1997.

Coram, Robert. Boyd: The Fighter Pilot Who Changed the Art of War. Boston: Brown Little, 2002.

Crozier, David. "Decisive Action: How to Fight and Sustain in the Army's Future Battles.” NCO Journal, May 28, 2013. Accessed March 26, 2015. http://ncojournal.dodlive.mil/ 2013/05/28/decisive-action-how-to-fight-and-sustain-in-the-armys-future-battles/.

DeWitt, John L. "Orientation, the Army War College Course, 1928-1929." 1928.

DiBella, Anthony J. “Can the Army Become a Learning Organization? A Question Reexamined.” US Army News. Accessed 01 Nov 2014, http://www.army.mil/ article/36320/Can_the_Army_Become_a_Learning_Organization_039_A_question_re examined/.

Downie, Richard D. Learning from Conflict: The U.S. Military in Vietnam, El Salvador, and the Drug War. Westport, CT: Praeger, 1998.

Field Manual 3-0, Operations. Washington, DC: Government Printing Office, 2008.

Field Manual 100-5, Field Service Regulations, Operations. Washington, DC: Government Printing Office, 1941.

Field Manual 100-5, Operations. Washington, DC: Government Printing Office, 1976.

Field Manual 100-5, Operations. Washington, DC: Government Printing Office, 1982.

Field Manual 100-5, Operations. Washington, DC: Government Printing Office, 1993.

Field Manual 100-5, Tentative Field Service Regulations, Operations. Washington, DC: Government Printing Office, 1939.

Field Service Regulations, United States Army 1913, corrected to May 21, 1913. Washington, DC: Government Printing Office, 1913.

Field Service Regulations, United States Army 1914, corrected to July 31, 1918. Washington, DC: Government Printing Office, 1918.

Field Service Regulations, United States Army 1923. Washington, DC: Government Printing Office, 1923.

Flood, Robert L. Rethinking the Fifth Discipline: Learning Within the Unknowable. London: Routledge, 1999. 
Gabel, Christopher R. The U.S. Army GHQ Maneuvers of 1941. Washington, DC: US Army Center of Military History, 1991.

Gentile, Gian P. “Let’s Build an Army to Win All Wars.” Joint Force Quarterly 52 (First Quarter 2009): 27-33.

Gerras, Stephen J. “The Army as a Learning Organization.” Research Paper, US Army War College, 2002.

Gole, Henry G. General William E. DePuy: Preparing the Army for Modern War. Lexington, KY: The University Press of Kentucky, 2008.

Gorman, Paul F. “Toward a Combined Arms Training Center.” Speech at TRADOC Conference. Fort Monmouth, NJ, November 9, 1976.

Griffin, Donald K. “If the Soviets Don’t Mass.” Military Review 59, no. 2 (February 1979): 5465.

Grotelueschen, Mark E. The AEF Way of War: The American Army and Combat in World War I. New York: Cambridge University Press, 2007.

Harrison, Benjamin L. A Review of Education and Training for Officers. 5 vols. Washington, DC: Headquarters, Department of the Army, 1978.

Heller, Charles E. “World War I and the Interwar Years, 1916-1939.” In A Brief History of Fort Leavenworth 1827-1983, edited by John W. Partin. Fort Leavenworth, KS: Combat Studies Institute, 1983.

Herbert, Paul H. Deciding What Has to Be Done: General William E. DePuy and the 1976 Edition of "FM 100-5: Operations" Leavenworth Papers No. 16. Fort Leavenworth, KS: Combat Studies Institute, 1988.

Hollis, Thomas S. "ILE a Casualty of War.” Monograph, US Army Command and General Staff College, 2008.

Johnson, David E. “From Frontier Constabulary to Modern Army.” In The Challenge of Change: Military Institutions and New Realities, 1918-1941, edited by Harold R. Winton and David R. Mets. Lincoln, NE: University of Nebraska Press, 2000.

Jones, Archer. “The New FM 100-5: A View From the Ivory Tower.” Military Review 58, no. 2 (February 1978): 27-36.

Kagan, Frederick W. “The Incredible Shrinking Army.” Weekly Standard 9, no. 35 (May 24, 2004): 14-15.

Kaufman, Aaron J. "Continuity and Evolution: General Donn A. Starry and Doctrinal Change in the U.S. Army, 1974-1982.” Monograph, US Army Command and General Staff College, 2008.

King, Benjamin. Victory Starts Here: A 35-year History of the US Army Training and Doctrine Command. Fort Leavenworth, KS: Combat Studies Institute Press, 2008.

Kohm, Barbara and Beverly Nance. Principals Who Learn: Asking the Right Questions, Seeking the Best Solutions. Alexandria, VA: Association for Supervision and Curriculum Development, 2007.

Kretchik, Walter E. U.S. Army Doctrine: From the American Revolution to the War on Terror. Lawrence, KS: University of Kansas Press, 2011. 
Lind, William S. “Some Doctrinal Questions for the United States Army.” Military Review 57, no. 3 (March 1977): 54-65.

Lock-Pullan, Richard. “'An Inward Looking Time’: The United States Army, 1973-1976.” The Journal of Military History 67, no. 2 (April 2003): 483-511.

"How to Rethink War: Conceptual Innovation and AirLand Battle Doctrine.” The Journal of Strategic Studies 28, no. 4 (August 2005): 679-702.

Loomis, Dan G. “FM 100-5 Operations: A Review.” Military Review 57, no. 3 (March 1977): 6669.

March, James and Johan P. Olsen. Ambiguity and Choice in Organization. Oslo: Universitetsforlaget, 1976.

Matheny, Michael R. Carrying the War to the Enemy: American Operational Art to 1945. Norman, OK: University of Oklahoma Press, 2011.

McHugh, John M. Army Directive 2012-21 Optimization of Intermediate-Level Education. Washington, DC: Government Printing Office, 2012

Moberg, Dennis J. “Diagnosing System States: Beyond Senge’s Archetypes” Emergence. 3(2), Lawrence Erlbaum Associates, Inc. 2001.

Moenk, Jean R. Operation STEADFAST Historical Summary: A History of the Reorganization of the U.S. Continental Army Command (1972 - 1973). Fort McPherson, GA: Headquarters, U.S. Army Forces Command, 1974.

Montague, Kareem P. “The Army and Team Learning.” Monograph, US Army Command and General Staff College, 2008.

Murray, Williamson A. “The West at War.” In The Cambridge History of Warfare, edited by Geoffrey Parker. New York: Cambridge University Press, 2005.

Nagl, John A. Learning to Eat Soup with a Knife: Counterinsurgency Lessons from Malaya and Vietnam. Chicago: The University of Chicago Press, 2005.

Norris, Frank. "Review of Army Officer Education System, Volume 1, Summary Report.” Fort Leavenworth, KS: Combined Arms Research Library, 1971.

Odom, William O. After the Trenches: The Transformation of U.S. Army Doctrine, 1918-1939. College Station, TX: Texas A\&M University Press, 1999.

Office of the Chief of Public Affairs. "Army Announces Optimization of Intermediate Level Education.” www.Army.mil, September 24, 2012. Accessed March 26, 2015. http://www.army.mil/article/87406.

Oseth, John M. “FM 100-5 Revisited: A Need for Better 'Foundation Concepts’?” Military Review 60, no. 3 (March 1980): 2-12.

Pappas, George S. Prudens Futuri: The US Army War College 1901 - 1967. Carlisle Barracks, PA: The Alumni Association of the US Army War College, 1967.

Partin, John W. “Wars and New Challenges, 1939-1983.” In A Brief History of Fort Leavenworth 1827-1983, edited by John W. Partin. Fort Leavenworth, KS: Combat Studies Institute, 1983.

Pershing, John J. "Wrapper Indorsement (Forwarding Report of A.E.F. Superior Board on Organization and Tactics).” General Headquarters, A.E.F., 1920. 
Peters, Ralph. “Learning to Lose.” American Interest 2, no. 6 (July/August 2007): 20-28.

Petraeus, David H. “To Ph.D. or Not to Ph.D....” American Interest 2, no. 6 (July/August 2007): 16-20.

Petty, Robert E. "Training vs. Education at the Army War College: The Benefits of a Return to the Past.” Monograph, US Army Command and General Staff College, 2014.

Reed, George E. “What's Wrong and What's Right With the War Colleges.” Defense Policy Journal, July 1, 2011. Accessed March 26, 2015. http://www.defensepolicy.org/georgereed/what\%E2\%80\%99s-wrong-and-right-with-the-war-colleges.

Romjue, John L. American Army Doctrine for the Post-Cold War. Fort Monroe, VA: Headquarters, Training and Doctrine Command, 1993.

- From Active Defense to AirLand Battle: The Development of Army Doctrine 1973-1982. Fort Monroe, VA: Headquarters, Training and Doctrine Command, 1984.

Romjue, John L., Susan Canedy and Anne W. Chapman. Prepare the Army for War: A Historical Overview of the Army Training and Doctrine Command, 1973-1993. Fort Monroe, VA: Headquarters, Training and Doctrine Command, 1993.

Schifferle, Peter J. America's School for War: Fort Leavenworth, Officer Education, and Victory in World War II. Lawrence, KS: University Press of Kansas, 2010.

Schneider, James J. “The Theory of the Empty Battlefield.” The RUSI Journal 132, no. 3 (September 1987): 37-44.

Senge, Peter M. The Fifth Discipline: The Art \& Practices of the Learning Organization. New York: Random House, Inc., 2006.

Senge, Peter M., Art Kleiner, Charlotte Roberts, Richard B. Ross, Bryan J. Smith. The Fifth Discipline Fieldbook: Strategies and Tools for Building a Learning Organization. New York: Doubleday, 1994.

Senge, Peter M., Nelda Cambron-McCabe, Timothy Lucas, Bryan Smith, Janis Dutton, and Art Kleiner. Schools That Learn: A Fifth Discipline Fieldbook for Educators, Parents, and Everyone Who Cares About Education. New York: Doubleday, 2000.

Serena, Chad C. Revolution in Military Adaptation: The US Army in the Iraq War. Washington, DC: Georgetown University Press, 2011.

Sisemore, James D. "Fort Leavenworth and its Education Legacy; Recommendations for ILE.” Monograph, US Army Command and General Staff College, 2012.

Spector, Ronald. “The Military Effectiveness of the U.S. Armed Forces, 1919-1939.” In On The Effectiveness of Military Institutions: Historical Case Studies from World War I, The Interwar Period, and World War II, vol. 2, The Interwar Period, edited by Allan Millett and Williamson Murray. 135-187. Columbus, OH: Mershon Center, 1986.

Starry, Donn A. “A Tactical Evolution - FM 100-5.” Military Review 58, no. 8 (August 1978): 211.

—_. "To Change an Army.” Military Review 63, no. 3 (March 1983): 20-27.

Steele, Dennis. "Decisive-Action Training Rotations: 'Old School Without Going Back in Time’.” Army 63, no. 2 (February 2013): 26-37. 
Stiehm, Judith H. In the Wake of War: U.S. Army War College: Military Education in a Democracy. Philadelphia: Temple University Press, 2002.

Summers, Jr., Harry G. On Strategy: A Critical Analysis of the Vietnam War. New York: Presidio Press, 1995.

Swain, Richard M. "Filling the Void: The Operational Art and the U.S. Army.” In Operational Art: Developments in the Theories of War, edited by B. J. C. McKercher and Michael A. Hennessy. Westport, CT: Praeger, 1996.

- Selected Papers of General William E. DePuy: First Commander, U.S. Army Training and Doctrine Command, 1 July 1973. Edited by Donald L Gilmore and Carolyn D. Conway. Fort Leavenworth, KS: Combat Studies Institute, 1994.

Tiron, Roxana. “Army Still Needs World-Class 'Red Force’ in Training Centers.” National Defense 89, no. 613 (December 2004): 40.

Training and Doctrine Command Pamphlet 350-70-12, The Army Distributed Learning (DL) Guide. Fort Eustis, VA: Headquarters, Training and Doctrine Command, 2013.

Training and Doctrine Command Pamphlet 525-3-0, The U.S. Army Capstone Concept. Fort Eustis, VA: Headquarters, Training and Doctrine Command, 2012.

Training and Doctrine Command Pamphlet 525-3-1, The U.S. Army Operating Concept: Win in a Complex World. Fort Eustis, VA: Headquarters, Training and Doctrine Command, 2014.

Training and Doctrine Command Pamphlet 525-8-2, The U.S. Army Learning Concept for 2015. Fort Monroe, VA: Headquarters, Training and Doctrine Command, 2011.

Training and Doctrine Command Pamphlet 525-8-3, The U.S. Army Training Concept 20122020. Fort Monroe, VA: Headquarters, Training and Doctrine Command, 2011.

Training Circular 7-100, Hybrid Threat. Washington, DC: Government Printing Office, 2010.

Transforming the Army: TRADOC's First Thirty Years 1973-2003. Fort Monroe, VA: Headquarters, Training and Doctrine Command, 2003.

United States Army Training and Doctrine Command. “About TRADOC.” US Army Training and Doctrine Command, October 28, 2014. Accessed March 28, 2015. http://www.tradoc.army.mil/About.asp.

United States Office of the Chairman of the Joint Chiefs of Staff. A Military History of the U.S. Army Command and General Staff College 1881 - 1963. Fort Leavenworth, KS: U.S. Army Command and General Staff College, 1964.

United States War Department. Annual Report of the Secretary of War, 1937. Washington, DC: Government Printing Office, 1937.

- Annual Report of the Secretary of War, 1938. Washington, DC: Government Printing Office, 1938.

- Annual Report of the Secretary of War, 1941. Washington, DC: Government Printing Office, 1941.

Wass de Czege, Huba. "Challenge for the Future: Educating Field Grade Battle Leaders and Staff Officers.” Military Review 64, no. 6 (June 1984): 2-13.

—_. "How to Change an Army.” Military Review 64, no. 11 (November 1984): 32-49. 
Williams, John D. “Is the U.S. Army a Learning Organization?” Strategy Research Project, US Army War College, 2007.

Young, Marilyn B. The Vietnam Wars 1945-1990. New York: HarperPerennial, 1991.

Zaltman, Gerald, Robert Duncan, and Jenny Holbeck. Innovation in Organizations. New York: John Wiley \& Sons, 1973. 